\title{
Diabetic gastroparesis: current challenges and future prospects
}

This article was published in the following Dove Press journal: Clinical and Experimental Gastroenterology

\author{
Danny J Avalos' \\ Irene Sarosiek' \\ Priyadarshini Loganathan ${ }^{2}$ \\ Richard W McCallum' \\ 'Division of Gastroenterology, Center \\ for Neurogastroenterology and GI \\ Motility, Texas Tech University Health \\ Sciences Center, El Paso, TX, USA; \\ 2Department of Internal Medicine, \\ Texas Tech University Health Sciences \\ Center El Paso, El Paso, TX, USA
}

\begin{abstract}
Diabetic gastroparesis (DMGP) is a condition of delayed gastric emptying after gastric outlet obstruction has been excluded. Symptoms of nausea, vomiting, early satiety, bloating, and abdominal pain are associated with DMGP. Uncontrolled symptoms can lead to overall poor quality of life and financial burdens on the healthcare system. A combination of antiemetics and prokinetics is used in symptom control; metoclopramide is the main prokinetic available for clinical use and is the only U.S. Food and Drug Administration-approved agent in the United States. However, a black box warning in 2009 reporting its association with tardive dyskinesia and recommending caution in chronically using this agent beyond 3 months has decreased its role in clinical practice. There is an unmet need for new prokinetics with good efficacy and safety profiles. Currently, there are several new drugs with different mechanisms of action in the pipeline that are under investigation and show promising preliminary results. Surgically combining gastric electrical stimulation with pyloroplasty is considered "gold" standard. Advances in therapeutic endoscopic intervention with gastric per-oral endoscopic pyloromyotomy have also been shown to improve gastric emptying and gastroparesis (GP) symptoms. In this review, we will comment on the challenges encountered when managing patients with DMGP and provide an update on advances in drug development and endoscopic and surgical interventions.
\end{abstract}

Keywords: bloating, fullness, nausea, vomiting, Enterra, diabetes

\section{Introduction}

Gastroparesis (GP) is a debilitating disease associated with poor quality of life (QoL) and financial burdens on the healthcare system. ${ }^{1}$ There is a paucity of data on the prevalence of diabetic gastroparesis (DMGP). Based on an epidemiological study from Olmsted county in Minnesota, the risk of GP in patients with type 1 diabetes mellitus (T1DM) and type 2 diabetes mellitus (T2DM) is $5.2 \%$ and $1.0 \%$, respectively. ${ }^{2}$ Clinical symptoms of DMGP include nausea/vomiting, early satiety, bloating, and abdominal pain. ${ }^{3,4}$ The basis for the diagnosis of DMGP relies on the exclusion of gastric outlet obstruction and a delayed gastric emptying (GE) study with a radionuclide-labeled solid meal. GE is considered delayed with a food bolus retention of $>60 \%$ at 2 hours and/or $>10 \%$ at 4 hours. ${ }^{5}$ Early satiety and postprandial fullness, two predominant symptoms in DMGP, have been associated with disease severity and delayed GE. ${ }^{6}$ Patients with T1DM-related GP, who account for $\sim 10 \%$ of the GP population, have comparable baseline symptoms to patients with T2DM-related GP. However, patients with T1DMrelated GP have less clinical improvement with medical and/or surgical treatment and more vascular complications from diabetes. ${ }^{7}$ Overall, patients with DMGP often have
Correspondence: Richard W McCallum Division of Gastroenterology, Center for Neurogastroenterology and GI Motility, Texas Tech University Health Sciences Center, 4800 Alberta Avenue, El Paso, TX, USA

Tel + I 915 215 5218

Fax +19152158641

Email richard.mccallum@ttuhsc.edu 
concomitant challenges with the management of hyperglycemia, and a vicious cycle is created, leading to worsening gastrointestinal neuropathy and clinical symptoms. ${ }^{8,9}$

The pathogenesis of DMGP remains elusive; however, it likely starts with impairment in the microcirculation of the gastric wall, ${ }^{10}$ which is also seen in other complications of diabetes (i.e., nephropathy and retinopathy). Loss of gastric neurons containing nitric oxide (NO) synthetase may ensue in patients with DMGP, and an impaired NO pathway in the myenteric plexus may lead to an impaired gastric accommodation reflex with subsequent dyspeptic symptoms ${ }^{11,12}$ (Figure 1). Damage to intrinsic/extrinsic neurons, ${ }^{13}$ loss of interstitial cells of Cajal (ICC), ${ }^{14}$ and loss of heme oxygenase $1(\mathrm{HO} 1)^{15}$ have also been implicated in DMGP. Lack of the protective enzyme heme oxygenase (HO1), which is expressed in type 2 macrophages against oxidative stress, has been associated with DMGP. ${ }^{16}$ Loss of CD206-positive antiinflammatory macrophages (M2) in circular muscles in the body ${ }^{17}$ and antrum ${ }^{18}$ of the stomach has been seen in conjunction with loss of ICC in patients with DMGP. Refractory DMGP has been associated with fewer ganglion cells and more depleted ICC in the inner circular layer than in idiopathic GP. ${ }^{19}$ Vagal cholinergics are also more often affected in DMGP than in idiopathic gastroparesis (IDGP). ${ }^{20}$ Murine models have suggested a potential link between reduced insu-
lin/IGF-1 signaling and subsequent ICC depletion, smooth muscle atrophy, and reduced stem cell factor production. ${ }^{21}$

Pyloric dysfunction is an overlooked aspect in the pathogenesis of GP. There is evidence of "pylorospasm" among patients with diabetes. ${ }^{22}$ Combined antral and pyloric dysfunction contribute to GP, with loss of relaxation in the pylorus and concomitant loss of antral motility. In addition, loss of ICC and smooth muscle fibrosis is more common in the pylorus than in the antrum of patients with refractory GP. ${ }^{23}$ The advent of the endoscopic functional luminal imaging probe (EndoFLIP) has allowed for the evaluation of pyloric dysfunction in DMGP. Symptoms of early satiety and postprandial fullness are inversely correlated with the diameter and cross-sectional area of the pyloric sphincter. ${ }^{24}$

In addition, wireless motility capsule testing has shown that there are extra-gastric delays in small bowel and colonic transit in up to $40 \%$ of patients with GP. ${ }^{25}$ Symptoms related to extra-gastric delays may be suboptimally addressed when treating patients with DMGP due to their lack of awareness.

\section{Antiemetics}

A search was conducted in MEDLINE up to August 1, 2017. Mesh and non-Mesh terms were used, including "gastroparesis," "therapeutics," "antiemetics," "clonidine," "nabinole," "dronabinol," “marinol," “cannabinoids," “ondansetron,"

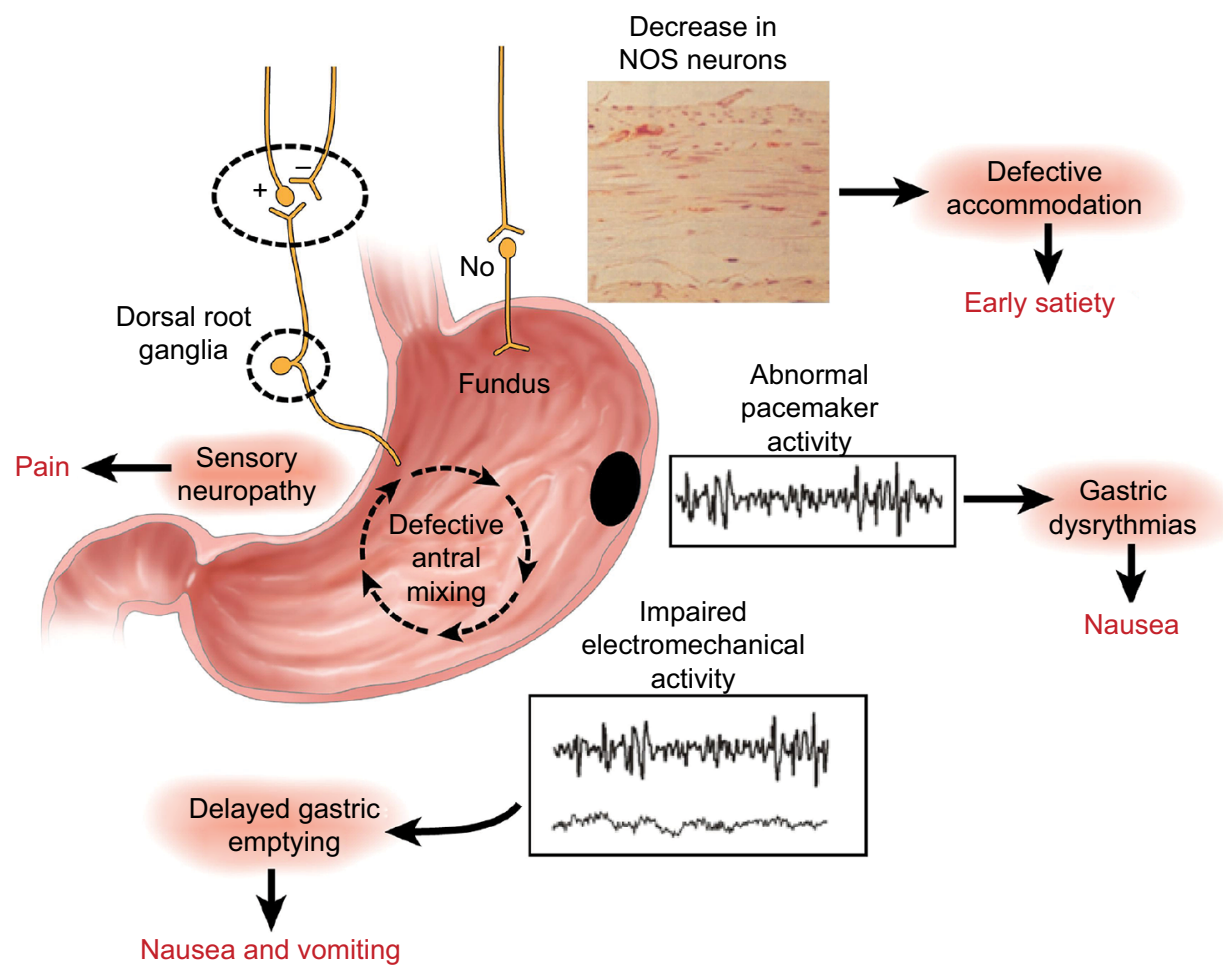

Figure I Summary of the neural, myoelectrical, muscular, and cellular aspects of the pathophysiology of gastroparesis.

Note: Reprinted from Gastroenterology, I4I(4), Owyang C, Phenotypic switching in diabetic gastroparesis: mechanism directs therapy, II34-II37, 20II, with permission from Elsevier. ${ }^{141}$ 
"'granisetron," "tropisetron," "dolasetron," and "aprepitant." Table 1 presents a summary of the antiemetics studied in DMGP, and Table 2 shows antiemetics commonly used in DMGP but not studied in prospective or clinical trials.

The scopolamine patch was adapted due to the inherent impediment of drug absorption during an episode of vomiting. Among 5-HT3 antagonists, granisetron is the only agent that can be administered via a transdermal patch, which is optimal during bouts of vomiting. It has been used in chemoinduced, radiation-induced, and postoperative nausea and vomiting. In a prospective study of 51 patients with GP (13 DMGP, 35 IDGP, 2 postsurgical GP, and 1 mixed connective tissue disease), $76 \%$ of patients reported clinical improvement in symptoms of nausea and vomiting $(p<0.05)$; however, less symptom improvement was seen among those with severely delayed GE ( $p=0.065) .{ }^{26}$ Aprepitant, a neurokinin-1 receptor antagonist, has been used for short-term treatment of chemotherapy-induced nausea, and its clinical benefit in refractory GP has been reported in a small case series. ${ }^{27}$ Most recently, the APRON (aprepitant for the treatment of nausea) randomized controlled trial evaluated the efficacy of $125 \mathrm{mg}$ of aprepitant daily $(n=63)$ vs. placebo $(n=63)$ for patients with nausea and vomiting due to suspected gastric dysfunction; $38 \%$ and $21 \%$ of the patients had diabetes in the aprepitant and placebo groups, respectively. Delayed GE was present in $46 \%$ of patients taking aprepitant and in $68 \%$ of those taking a placebo, whereas rapid GE was present in $3 \%$ of patients in each arm. Overall, the primary endpoint of reduction in nausea was not different from that of placebo ( $46 \%$ vs. $40 \%, p=0.43$ ); however, there were improvements in overall symptom relief $(\mathrm{p}=0.001)$ and reductions in gastroparesis cardinal symptom index (GCSI) scores for nausea $(p=0.005)$ and vomiting $(p=0.001)$ in patients taking aprepitant. ${ }^{28,29}$ Tradipitant (VLY-686), a drug similar to aprepitant, is a neurokinin-1 receptor antagonist that works by blocking substance $\mathrm{P}$; it is now undergoing clinical trial evaluation. ${ }^{30}$

In a small randomized trial of patients with DMGP, oral clonidine, an alpha-2 adrenergic agonist, reduced symptoms of nausea and vomiting. Ten patients with DMGP and 10 matched controls received oral clonidine in doses ranging from 0.1 to $0.3 \mathrm{mg}$ BID. GE of a solid meal was no different between the groups ( $p=0.62$ ); however, symptoms of nausea and vomiting were reduced in patients with DMGP. ${ }^{31}$ In a separate case series, six patients with diabetes with refractory symptoms of bloating, nausea, and vomiting received a median dose of $0.3 \mathrm{mg}$ of clonidine per day and had a significant improvement in GE $\mathrm{t}_{1 / 2}$ of a liquid meal $(p<0.025)$ and overall symptoms. ${ }^{32}$ It is postulated that the therapeutic effect of clonidine comes from its action on the alpha- 2 adrenergic receptor in the chemoreceptor trigger zone. ${ }^{33}$

The impact of acupuncture on the symptoms of DMGP has been an active area of investigation. In a prospective nonrandomized, unblinded case-crossover study of eight patients with DMGP who were on domperidone $(20 \mathrm{mg}$ QID) for 12 weeks with a washout period of 2-3 weeks, the patients received acupuncture biweekly for 8 weeks. There was no change in GCSI scores with domperidone ( $p=0.77)$; however, there was improvement in the majority of the cardinal symptoms for GCSI ( $p=0.079)$ and QoL after acupuncture $(p=0.002) .{ }^{34}$ In a meta-analysis of low-quality randomized trials, acupuncture treatment had a higher response for the improvement of dyspeptic symptoms than controls (RR 1.20, CI: $1.12-1.29 ; p<0.00001) .{ }^{35}$ These data should be regarded with caution due to the possibility of publication bias. Our research group has evaluated the effect of transcutaneous acupuncture (TEA) in the treatment of nausea in patients with GP. Using electroencephalography and electrogastrography, 11 patients with DMGP showed improvement with TEA in terms of gastric dysrhythmia and reduction of nausea $(p<0.05) .{ }^{36}$ To date, no clinical trials have evaluated marijuana or tetrahydrocannabinol (THC) derivatives (i.e., nabinol or dronabinol) in the treatment of GP symptoms. THC derivatives are likely to be ineffective for the long-term treatment of DMGP since they delay $\mathrm{GE}^{37}$ and may lead to cannabinoid hyperemesis syndrome. ${ }^{38}$

\section{Prokinetics}

A search was conducted in MEDLINE up to August 1, 2017. Mesh and non-Mesh terms were used, including "gastroparesis", "prokinetics", “azithromycin", "erythromycin", "metoclopramide", "domperidone", and "metopimazine". Table 3 shows the prokinetics used in DMGP.

Oral metoclopramide has been the mainstay treatment in DMGP since its approval by the U.S. Food and Drug Administration (FDA) in $1980 .{ }^{39}$ Metoclopramide is a D2-dopamine receptor antagonist that increases lower esophageal sphincter (LES) pressure, GE, and transit time in the proximal small bowel. It also has an antiemetic effect via its antagonistic effects on dopamine receptors in the chemoreceptor trigger zone. ${ }^{40}$ However, in 2009, a black box warning was issued on metoclopramide due to its association with tardive dyskinesia. ${ }^{41}$ This black box warning led to legal implications and has decreased its use in clinical practice. ${ }^{42}$

A study of genetic polymorphisms in the recipients of metoclopramide for upper gastrointestinal symptoms suggestive of GP revealed that side effects were associated with 


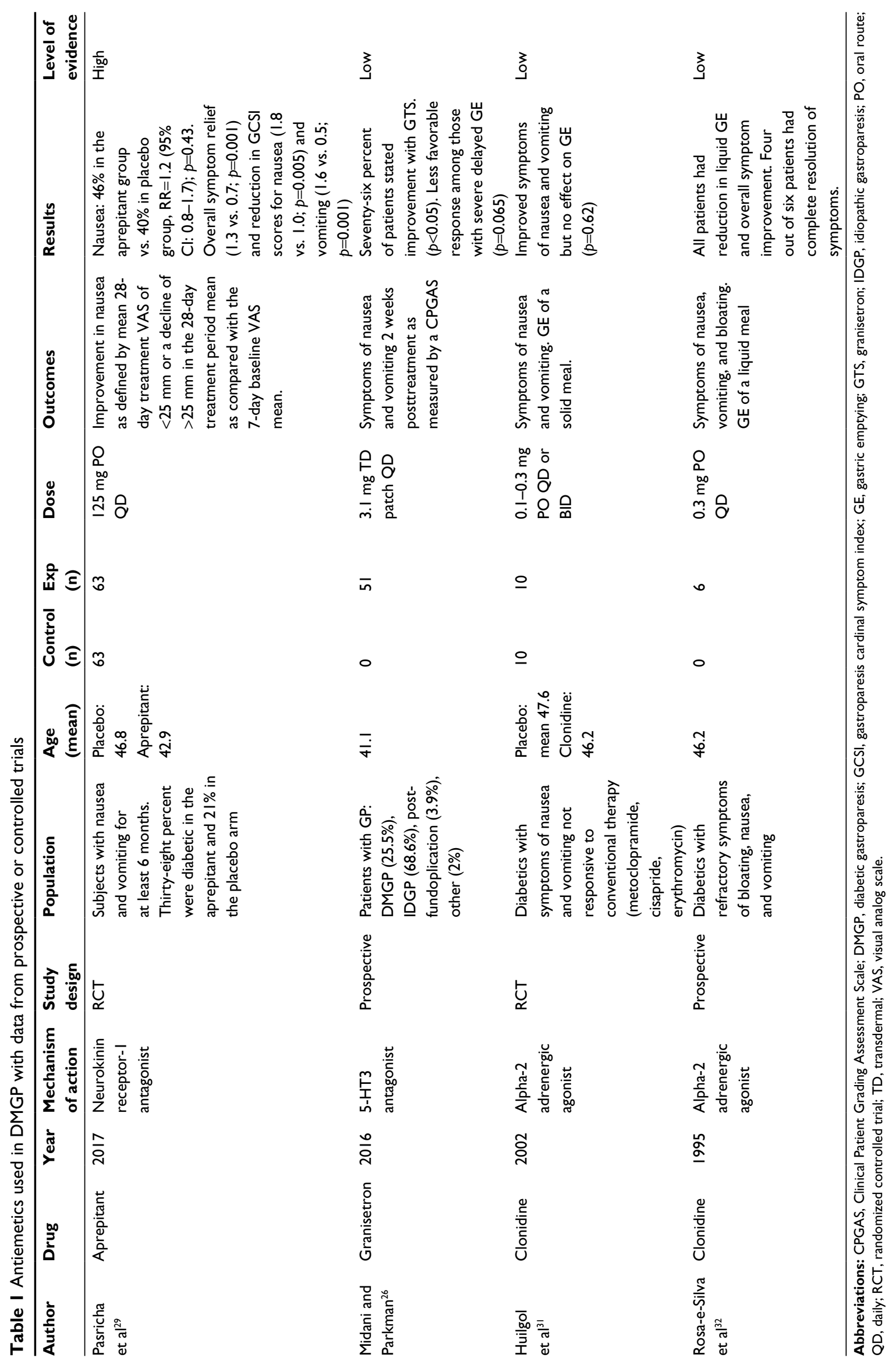


Table 2 Antiemetics used but not studied in prospective or clinical trials

\begin{tabular}{ll}
\hline Receptor & Drug \\
\hline 5-HT3 antagonists & Ondansetron, tropisetron, dolasetron \\
Cannabinoid receptor agonist & Marinol, dronabinol, nabilone \\
Anticholinergic/antihistamines & $\begin{array}{l}\text { Scopolamine transdermal patch, } \\
\text { promethazine }\end{array}$ \\
\hline
\end{tabular}

polymorphisms in CYP2D6, KCNH2, and 5-HT4 receptor HTR4 genes, and good clinical response was associated with polymorphisms in KCNH2 and ADRA1D. ${ }^{43}$ In an openlabel randomized trial evaluating patients with DMGP, a nasal spray containing 10 or $20 \mathrm{mg}$ of metoclopramide was compared with metoclopramide $10 \mathrm{mg}$ oral tablets QID $\times 6$ weeks. Total symptom scores were better with the administration of $20 \mathrm{mg}(p=0.008)$ and $10 \mathrm{mg}(p=0.03)$ nasal spray metoclopramide than with oral metoclopramide. ${ }^{44} \mathrm{~A}$ Phase III randomized multicenter trial also evaluated nasal metoclopramide at $10 \mathrm{mg}$ QID vs. placebo for 28 days. A total of 205 women with DMGP (88\% T2DM) with a mean age of 52.7 years were included in the trial. The primary endpoint of reduction in baseline symptoms at week 4 was not met; however, a subgroup analysis of patients with moderatesevere symptoms at baseline showed a significant reduction of symptoms at weeks 1 and 3. There were no differences in adverse events between either arm..$^{45}$

Domperidone has been associated with improvement in symptoms of postprandial fullness, nausea, and vomiting. ${ }^{46-59}$ This dopamine 2 antagonist differs from metoclopramide in that it does neither cross the blood-brain barrier nor induces central nervous system side effects but has a similar efficacy profile to that of oral metoclopramide. ${ }^{55}$ It has been utilized worldwide for over 25 years, but it is available only in the United States under an investigational new drug application through the FDA. In a prospective cohort (88 IDGP, 16 DMGP, and 9 postsurgical GP), most patients showed an improvement in GP symptoms, including nausea, vomiting, retching, early satiety, postprandial fullness, and upper abdominal pain $(p<0.001) .{ }^{56}$ Similarly, a recent prospective cohort of 34 patients (5 DMGP and 29 IDGP) taking domperidone at $10 \mathrm{mg}$ TID for an average treatment duration of 36.9 days showed an overall GP symptom improvement $(p<0.05){ }^{48}$ In a systematic review of 28 trials (11 full articles and 17 abstracts), $64 \%$ of studies showed a symptom improvement, $60 \%$ showed an improvement in GE, and $67 \%$ of studies showed a reduction in hospital readmissions. It was concluded that there is level 3 evidence for the efficacy of domperidone in DMGP, leading to a grade $\mathrm{C}$ recommendation. " ${ }^{60}$ "New" domperidone formula- tions have been developed to minimize the remote possibility of cardiotoxicity (prolonged QT interval) with the original domperidone. NG101 (metopimazine) has shown promising results in animal models and is a highly potent $\mathrm{D} 2$ receptor antagonist $(100 \times$ more potent than metoclopramide $)$ that does not cross the blood-brain barrier or antagonize hERG channels (cardiac channels) in vitro. ${ }^{61}$ Similarly, TAK-906 is being evaluated in Phase II clinical studies to assess the safety of the drug in patients with DMGP and IDGP in a randomized double-blind trial.

Erythromycin is a macrolide antibiotic with an agonist effect on the motilin receptor, ${ }^{62}$ and IV or oral erythromycin administration may improve GE by $30 \%-60 \% .{ }^{63}$ Motilin, a polypeptide hormone, increases LES pressure and initiates migrating motor complex (MMC) activity in the antrum and proximal small bowel. ${ }^{64}$ Intravenous erythromycin at doses of $6 \mathrm{mg} / \mathrm{kg}$ followed by an oral erythromycin base at a dose of $500 \mathrm{mg}$ TID prior to meals has been shown to improve solid meal retention at 2 hours from $85 \%$ at baseline vs. $20 \%$ following intravenous erythromycin $(p<0.001)$ and $48 \%$ after 4 weeks of oral therapy $(p<0.01) \cdot{ }^{65}$ However, a randomized trial of motilin receptor agonist (ABT-229) vs. placebo failed to show an improvement in clinical symptoms in patients with T1DM with or without delayed GE. ${ }^{66}$ Furthermore, the effects of erythromycin may only be short lived due to the development of tachyphylaxis with prolonged use. ${ }^{67} \mathrm{~A}$ similar macrolide, azithromycin, has also been shown to improve antral and duodenal contractions in patients with gastrointestinal dysmotility; however, unlike erythromycin, it has fewer drug-drug interactions and is not metabolized by the $\mathrm{P} 450$ system. ${ }^{68,69} \mathrm{~A}$ prospective study of 120 patients with chronic abdominal pain or suspected GP underwent solid meal GE with IV azithromycin or $250 \mathrm{mg}$ of IV erythromycin given at 75-80 minutes with 15 minutes of further imaging to determine $\mathrm{GE}_{1 / 2}$. $\mathrm{GE}_{1 / 2}$ was comparable between azithromycin (mean GE $t_{1 / 2} 10.4 \pm 7.2$ minutes) and erythromycin (mean GE $\mathrm{t}_{1 / 2} 11.9 \pm 8.4$ minutes; $p=0.30$ ). Due to the fewer drug-drug interactions, a lower incidence of QT prolongation, and a longer half-life with azithromycin, it may be a better alternative to erythromycin ${ }^{70}$; however, concerns about antimicrobial stewardship may limit its long-term use.

\section{Advances in drug development}

The need for further drug development for GP continues, and several agents are poised to gain acceptance (Table 4). Traditionally, endpoints in clinical trials have focused on enhancing GE and evaluating GCSI scores. Even though prokinetics have been associated with clinical improvement 
Table 3 Prokinetics in DMGP

\begin{tabular}{|c|c|c|c|c|c|c|}
\hline Author & Drug & Dose & Year & $\begin{array}{l}\text { Study } \\
\text { Design }\end{array}$ & Population & Age (mean) \\
\hline $\begin{array}{l}\text { Heckert and } \\
\text { Parkman }\end{array}$ & Domperidone & $\begin{array}{l}10 \text { mg PO TID for } 6 \\
\text { weeks }\end{array}$ & 2017 & Prospective & $\begin{array}{l}\text { Refractory GP patients: DMGP } \\
(14.7 \%) \text {, IDGP }(85.3 \%)\end{array}$ & 44 \\
\hline Schey et $\mathrm{a}^{56}$ & Domperidone & $\begin{array}{l}\text { I0-20 mg PO TID or } \\
\text { QID }\end{array}$ & 2016 & Prospective & $\begin{array}{l}\text { Refractory GP: DMGP (I3.9\%), IDGP } \\
\text { (76.5\%), postsurgical GP ( } 7.8 \%) \text {, other } \\
(1.7 \%)\end{array}$ & 41 \\
\hline Ortiz et al ${ }^{54}$ & Domperidone & $\begin{array}{l}40-120 \mathrm{PO} \mathrm{mg} / \mathrm{day} ; \\
10-40 \mathrm{mg} \\
30 \text { minutes before each } \\
\text { meal and at bedtime }\end{array}$ & 2015 & Retrospective & $\begin{array}{l}\text { Refractory GP: DMGP ( } 45 \%) \text {, IDGP } \\
(36 \%) \text {, chronic nausea and vomiting } \\
(8 \%) \text {, dumping syndrome }(5 \%) \text {, cyclic } \\
\text { vomiting syndrome }(5 \%) \text {, conditioned } \\
\text { vomiting ( } 1 \%)\end{array}$ & 40 \\
\hline $\begin{array}{l}\text { Franzese } \\
\text { et } \mathrm{al}^{47}\end{array}$ & Domperidone & $\begin{array}{l}0.9 \mathrm{mg} / \mathrm{kg} \text { PO TID } \\
\text { Cisapride } 0.8 \mathrm{mg} / \mathrm{kg} \text { PO } \\
\text { TID }\end{array}$ & 2002 & RCT & Children with IDDM and GP & 12 \\
\hline $\begin{array}{l}\text { Patterson } \\
\text { et al }{ }^{55}\end{array}$ & Domperidone & 10 mg PO QID & 1999 & RCT & $\begin{array}{l}\text { IDDM patients with a 3-month history } \\
\text { of GP }\end{array}$ & 39 \\
\hline Silvers et $\mathrm{a}^{57}$ & Domperidone & 20 mg PO QID & 1998 & RCT & DMGP & 45 \\
\hline $\begin{array}{l}\text { Soykan } \\
\text { et al }\left.\right|^{58}\end{array}$ & Domperidone & 20 mg PO QID & 1997 & Prospective & GP & 42.8 \\
\hline Kozarek $^{52}$ & Domperidone & $40-80 \mathrm{mg}$ PO QD & 1990 & Retrospective & DMGP & 39 (Median) \\
\hline Braun $^{46}$ & Domperidone & 10 mg PO QID & 1989 & $\mathrm{RCT}$ & DMGP & 51 \\
\hline Koch et $\mathrm{al}^{51}$ & Domperidone & $20 \mathrm{mg}$ PO QID & 1989 & $\begin{array}{l}\text { Open-labeled } \\
\text { trial }\end{array}$ & IDDM with upper GI symptoms & 45 \\
\hline $\begin{array}{l}\text { Horowitz } \\
\text { et al }\left.\right|^{50}\end{array}$ & Domperidone & 20 mg PO TID & 1985 & $\begin{array}{l}\text { Open-labeled } \\
\text { trial }\end{array}$ & $\begin{array}{l}\text { IDDM patients with autonomic } \\
\text { neuropathy }\end{array}$ & $2 I-6 I$ (range) \\
\hline Watts et a ${ }^{59}$ & Domperidone & 10 mg PO QID & 1985 & $\begin{array}{l}\text { Open-labeled } \\
\text { trial }\end{array}$ & DMGP & 40.3 \\
\hline Heer et $\mathrm{a}^{49}$ & Domperidone & $10 \mathrm{mg}$ IV & 1983 & $\mathrm{RCT}$ & DMGP & 45.8 \\
\hline $\begin{array}{l}\text { Nagler and } \\
\text { Miskovitz }^{53}\end{array}$ & Domperidone & 10 mg PO QID & 1981 & RCT & Chronic idiopathic upper Gl distress & NR \\
\hline $\begin{array}{l}\text { McCallum } \\
\text { et al }{ }^{45 \Lambda}\end{array}$ & $\begin{array}{l}\text { Metoclopramide } \\
\text { nasal spray }\end{array}$ & $\begin{array}{l}10 \mathrm{mg} \text { nasal } \\
\text { metoclopramide vs. } \\
\text { placebo QID }\end{array}$ & 2017 & RCT & DMGP (women) & 52.7 \\
\hline $\begin{array}{l}\text { Parkman } \\
\text { et } \mathrm{al}^{44}\end{array}$ & $\begin{array}{l}\text { Metoclopramide } \\
\text { tablet vs. nasal } \\
\text { spray }\end{array}$ & $\begin{array}{l}10-20 \mathrm{mg} \text { nasal spray vs. } \\
10 \mathrm{mg} \text { tablet PO QID }\end{array}$ & 2014 & RCT & & $\begin{array}{l}54.3 \text { (control) } \\
55.5 \text { (I0 mg nasal), } \\
53.8 \text { (20 mg nasal) }\end{array}$ \\
\hline $\begin{array}{l}\text { Camilleri } \\
\text { et } \mathrm{al}^{75}\end{array}$ & Relamorelin & $\begin{array}{l}10 \mu g \text { s.c BID, } 30 \mu g \text { s.c } \\
\text { BID, } 100 \mu g \text { BID }\end{array}$ & 2017 & RCT & DMGP with moderate to severe GP & 58.2 (median) \\
\hline $\begin{array}{l}\text { Lembo } \\
\text { et } \mathrm{al}^{76}\end{array}$ & Relamorelin & $\begin{array}{l}100 \mu g \text { s.c QD, BID or } \\
\text { placebo }\end{array}$ & 2016 & RCT & $\begin{array}{l}\text { Adults with GP symptoms and delayed } \\
\text { GE (I3C-spirulina GE breath test) }\end{array}$ & $\begin{array}{l}\text { Placebo: } 55.2 \text { (I I.I2) } \\
\text { Relamorelin } \\
\text { QD: } 56.2 \text { (I0.74) } \\
\text { Relamorelin BID: } \\
53.5(10.7 I)\end{array}$ \\
\hline Shin et $\mathrm{al}^{73}$ & Relamorelin & $\begin{array}{l}100 \mu g \text { s.c single dose or } \\
\text { placebo }\end{array}$ & 2013 & RCT & TIDM patients with prior delayed GE & $\begin{array}{l}\text { Relamorelin: } \\
45.7 \pm 4.4\end{array}$ \\
\hline Shin et $\mathrm{al}^{74}$ & Relamorelin & $\begin{array}{l}100 \mu g \text { s.c. single dose or } \\
\text { placebo }\end{array}$ & 2013 & $\mathrm{RCT}$ & Women with DMGP & 51.8 \\
\hline
\end{tabular}

Note: ^indicates study reported in abstract form.

Abbreviations: DMGP, diabetic gastroparesis; EEG, electrogastrography; GCSI-DD, gastroparesis cardinal symptom index-daily diary; GET, gastric emptying time; GI, gastrointestinal; GP, gastroparesis; IDDM, insulin-dependent diabetes mellitus; IDGP, idiopathic gastroparesis; NVFP, nausea vomiting fullness pain; NR, not reported; QoL, quality of life; RCT, randomized controlled trial; TIDM, type I diabetes mellitus; TSS, total symptom score. 


\begin{tabular}{|c|c|c|c|c|}
\hline $\begin{array}{l}\text { Control } \\
\text { (n) }\end{array}$ & $\begin{array}{l}\operatorname{Exp} \\
(n)\end{array}$ & Outcomes & Results & $\begin{array}{l}\text { Level of } \\
\text { evidence }\end{array}$ \\
\hline 0 & 34 & GCSI-DD & $\begin{array}{l}\text { Overall symptoms improved (early satiety, postprandial fullness, } \\
\text { and nausea), } p<0.05\end{array}$ & Moderate \\
\hline 0 & 115 & $\begin{array}{l}\text { Clinical Patient Grading Assessment } \\
\text { Scale } \\
(+7=\text { completely better; } 0=\text { no change). }\end{array}$ & $\begin{array}{l}\text { Sixty percent of patients reported symptom improvement } \\
\text { (postprandial fullness, nausea, vomiting, stomach fullness), } 38 \% \\
\text { had side effects (headache, tachycardia, diarrhea), and I2\% had } \\
\text { side effects requiring medication discontinuation }\end{array}$ & \\
\hline 0 & 64 & $\begin{array}{l}\text { QTc prolongation, Gl symptoms based } \\
\text { on a 7-point Likert scale }\end{array}$ & $\begin{array}{l}\text { Seventy-three percent of patients had a moderate improvement } \\
\text { in symptoms }\end{array}$ & \\
\hline 13 & 14 & Clinical symptoms, EGG & $\begin{array}{l}\text { Symptomatic score was markedly lower in domperidone group } \\
\text { than in cisapride group } p<0.01 \text {. Domperidone normalized gastric } \\
\text { electrical activity }(p<0.05) \text { and decreased the prevalence of } \\
\text { episodes of gastric dysrhythmia }(p<0.01)\end{array}$ & \\
\hline 45 & 48 & $\begin{array}{l}\text { Nausea, vomiting, bloating, distension, } \\
\text { early satiety }\end{array}$ & $\begin{array}{l}\text { Similar efficacy between domperidone and metoclopramide but } \\
\text { less somnolence with the domperidone }\end{array}$ & \\
\hline 103 & 287 & QoL, clinical symptoms & Significant improvement in Gl symptoms and improvement in QoL & \\
\hline 0 & 17 & $\begin{array}{l}\text { Gastroparesis symptom scores and } \\
\text { QoL }\end{array}$ & $\begin{array}{l}\text { GP symptom scores were reduced from } 4.1 \pm 0.22(\text { mean } \pm \text { SEM) } \\
\text { to } 1.3 \pm 0.2\end{array}$ & \\
\hline 0 & 57 & Global response & $\begin{array}{l}\text { Seventy percent had a marked or moderate response, } 26 \% \text { had } \\
\text { slight response or no change, } 4 \% \text { had worsening of symptoms }\end{array}$ & \\
\hline 0 & 18 & Anorexia, nausea, vomiting, early satiety & Decrease in symptom frequency and intensity & \\
\hline 0 & 6 & $\begin{array}{l}\text { GE (solids), and gastric myoelectric } \\
\text { activity }\end{array}$ & $\begin{array}{l}\text { Gl symptom score improved from } 17.8 \text { to } 3.7 \text { ( } p \leq 0.01) \text {. No } \\
\text { change in GE }\end{array}$ & \\
\hline 22 & 12 & GET & Improvement in GET of both solids and liquids, $p \leq 0.00 \mathrm{I}$ & \\
\hline 0 & 3 & GET & Symptomatic improvement with no adverse effects & \\
\hline 0 & 6 & GET & Shortened GE tl/2 & \\
\hline 0 & 11 & Clinical symptoms & No differences between domperidone and placebo & \\
\hline 53 & 52 & $\begin{array}{l}\text { Change from baseline in symptom } \\
\text { score at week } 4\end{array}$ & $\begin{array}{l}\text { No significant differences }(p=0.9) \text { between nasal spray } \\
\text { metoclopramide and placebo at week } 4 \text {. Within the moderate- } \\
\text { severe cohort, a significant treatment effect favoring the nasal } \\
\text { metoclopramide spray }(p<0.05) \text { was seen at weeks I-3 }\end{array}$ & Moderate \\
\hline 18 & 71 & TSS, Responder & $\begin{array}{l}\text { Change from baseline in TSS for nasal } 20 \mathrm{mg} \text { was }>10 \mathrm{mg} \text { of } \\
\text { oral metoclopramide at week } 6(p=0.03) \text {. Significant difference } \\
\text { between baseline TSS and week } 6 \text { with } 10 \mathrm{mg}(p=0.03) \text { or } 20 \mathrm{mg} \\
(p=0.008) \text { nasal metoclopramide }\end{array}$ & \\
\hline 104 & 289 & Clinical symptoms and GE & $\begin{array}{l}\text { Seventy-five percent reduction in vomiting frequency compared } \\
\text { with baseline, but this difference was not significant compared } \\
\text { with the placebo group. Relamorelin improved overall composite } \\
\text { symptoms and accelerated GE by } 12 \% \text { compared with placebo } \\
(p<0.05)\end{array}$ & High \\
\hline 69 & 135 & $\begin{array}{l}\text { GE (solid meal) as measured by a } \\
\text { I3C-spirulina GE breath test } \\
\text { Secondary outcomes: nausea, } \\
\text { abdominal pain, bloating, early satiety, } \\
\text { and vomiting frequency and severity }\end{array}$ & $\begin{array}{l}\text { Twice-daily relamorelin significantly accelerated GE }(p<0.03) \text { and } \\
\text { reduced vomiting frequency (by } \sim 60 \%) \text { and severity vs. placebo } \\
(p \leq 0.03)\end{array}$ & \\
\hline 5 & 5 & $\begin{array}{l}\text { GE (solids and liquids), GCSI-DD, } \\
\text { nausea, vomiting, fullness, } \\
\text { and pain scores }\end{array}$ & $\begin{array}{l}\text { Single-dose RM- }|3| \text { decreased gastric retention of solids at I } \\
\text { hour }(p=0.005) \text { and } 2 \text { hours }(p=0.0 \text { I9). Relamorelin reduced } \\
\text { GCSI-DD scores }(p=0.03) \text { and NVFP scores }(p=0.04)\end{array}$ & \\
\hline 3 & 10 & GE of a solid meal & $\begin{array}{l}\text { GE } \mathrm{t} \mathrm{I} / 2 \text { solid }(\mathrm{min}) \text { : relamorelin: } 59.5 \pm 7.9 \text {, placebo: } 127.8 \pm 18.6 \text {, } \\
p=0.0 \mathrm{I}\end{array}$ & \\
\hline
\end{tabular}


Table 4 Prokinetics in Phase II and III stages of development

\begin{tabular}{|c|c|c|c|}
\hline Drug name & $\begin{array}{l}\text { Route of } \\
\text { administration }\end{array}$ & $\begin{array}{l}\text { Mechanism } \\
\text { of action }\end{array}$ & $\begin{array}{l}\text { Clinicaltrials.gov } \\
\text { identifier }\end{array}$ \\
\hline $\begin{array}{l}\text { Metoclopramide } \\
\text { nasal spray } \\
\text { (Evoke pharma) }\end{array}$ & Intranasal & $\begin{array}{l}\text { Dopamine } \\
\text { (D2) receptor } \\
\text { antagonist }\end{array}$ & NCT00845858 \\
\hline $\begin{array}{l}\text { Domperidone } \\
\text { (new) } \\
\text { (TAK906- } \\
\text { Takeda, NG }\end{array}$ & Oral & $\begin{array}{l}\text { Dopamine } \\
\text { receptor } \\
\text { antagonist } \\
(\mathrm{D} 2 / \mathrm{D} 3)\end{array}$ & NCT0326894I \\
\hline $10 \mid$-neurogastrix) & & & \\
\hline $\begin{array}{l}\text { Prucalopride } \\
\text { (Shire) }\end{array}$ & Oral & $\begin{array}{l}\text { 5-HT4R } \\
\text { agonist }\end{array}$ & NCT0203I08I \\
\hline $\begin{array}{l}\text { Velusetrag } \\
\text { (Theravance } \\
\text { biopharma) }\end{array}$ & Oral & $\begin{array}{l}\text { 5-HT4R } \\
\text { agonist }\end{array}$ & NCT02267525 \\
\hline $\begin{array}{l}\text { Relamorelin } \\
\text { (RM-I3I) } \\
\text { (Allergan) }\end{array}$ & Subcutaneous & $\begin{array}{l}\text { Selective ghrelin } \\
\text { receptor agonist }\end{array}$ & NCT02357420 \\
\hline
\end{tabular}

Abbreviations: 5-HT4R, 5-hydroxytryptamine-4 receptor; NA, not available.

and accelerated GE, establishing a correlation between symptom improvement and changes in GE has been elusive for drugs such as metoclopramide, domperidone, cisapride, erythromycin, and levosulpiride. The lack of a relationship between these two outcomes has led to questioning of the use of GE as a primary endpoint in drug development. ${ }^{71}$

Ghrelin promotes gastric motility and has been shown to relieve GP symptoms (Figure 2). ${ }^{72,73}$ Relamorelin (RM-131), a selective ghrelin receptor agonist, accelerated solid GE $\mathrm{t}_{1 / 2}(p=0.01)$ in a Phase $\mathrm{Ib}$ clinical trial ${ }^{74}$ with a reduction in clinical symptoms $(p<0.05)$ and improved GE in a Phase IIb randomized trial of patients with moderate-severe diabetic GP who received 10 or $30 \mu \mathrm{g}$ of subcutaneous relamorelin BID vs. placebo $(p<0.05) .{ }^{75}$ Similarly, a double-blind Phase II randomized trial including 204 patients with DMGP from 27 clinical centers received $10 \mu \mathrm{g}$ of relamorelin subcutaneously once or twice daily. Twice a day dosing accelerated GE $(p<0.03)$ with a decrease in vomiting episodes of nearly $60 \%$ ( $p \leq 0.03) .{ }^{76}$ Currently, a multicenter Phase III randomized trial has started for relamorelin at a dose of $10 \mu \mathrm{g}$ BID in DMGP.

Pharmacologic agents working as 5HT4 receptor agonists have been shown to enhance GE and small bowel and colonic transit and mediate reflexes controlling gastrointestinal motility and secretion. ${ }^{77-79}$ Historically, cisapride ${ }^{80}$ and tegaserod ${ }^{81}$ were developed based on these mechanisms but were not sustainable due to cardiotoxicity. ${ }^{82}$ Prucalopride, a selective 5-hydroxytryptamine-4 receptor agonist, has been evaluated in patients with DMGP and IDGP with improvement in GE $\mathrm{t}_{1 / 2}$ emptying $(p<0.05)$ and GCSI scores, including fullness/ satiety $(p<0.0005)$, nausea/vomiting $(p<0.001)$, and bloating/ distension $(p<0.00001)$, compared with placebo. ${ }^{83}$ Velusetrag, a 5-HT4 agonist, was evaluated in patients with GP (53\% diabetes) in a randomized crossover placebo-controlled study evaluating dosing regimens of 5,10 , and $30 \mathrm{mg} /$ day.

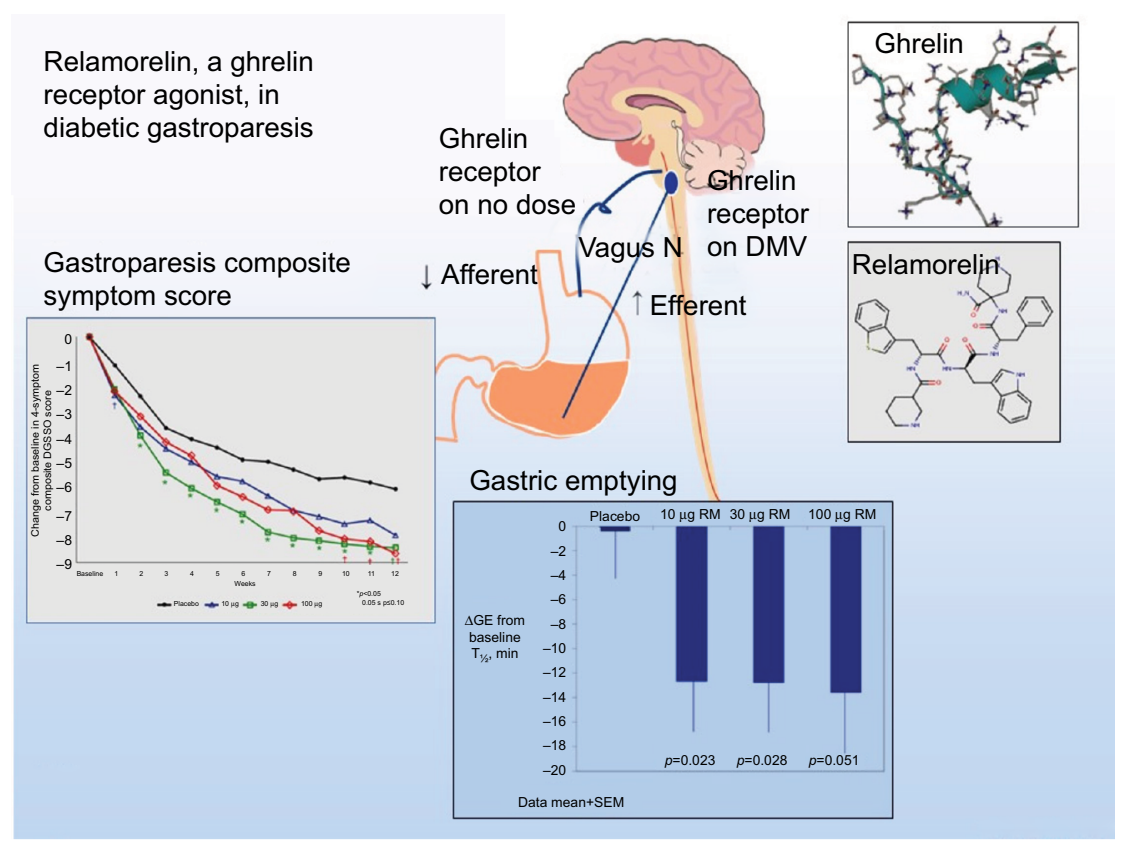

Figure 2 Summary of the molecular structure, mechanism of action, and outcomes of a clinical trial regarding symptoms and gastric emptying. Note: Image courtesy from Dr Michael Camilleri from the Mayo Clinic's Division of Gastroenterology in Rochester, MN, USA.

Abbreviations: DMV, dorsal motor nucleus of the vagus; GE, gastric emptying; RM, relamorelin; SEM, standard error of the mean. 
Improvement in GE time, as defined by a $20 \%$ reduction of $\mathrm{GE} \mathrm{t}_{1 / 2}$, was achieved in $52 \%$ of patients (with both diabetic and idiopathic GP) with the $30 \mathrm{mg} /$ day dose compared with placebo $(p=0.002) .{ }^{84}$ Pharmacologic receptor data have shown that Velusetrag is $500 \times$ more selective than cisapride without cardiotoxicity. ${ }^{85}$

\section{Basic cellular level therapies}

Macrophage phenotype and loss of ICC in the gastric muscle layers have led to cellular explanations for delayed GE. In diabetic models, macrophages with the M2 phenotype show normal GE, whereas in vitro studies have shown that the M1 phenotype leads to tumor necrosis factor- $\alpha$ production, resulting in Kit loss and ICC injury. ${ }^{86}$ Furthermore, low numbers of CD206-positive M2 macrophages in the body ${ }^{17}$ and antrum ${ }^{18}$ of human subjects have been associated with ICC loss and DMGP. Based on this notion, pioglitazone (thiazolidinedione class) could have the potential to modify these changes of depleted CD206 M2 macrophages in the stomach.

Similarly, reduction in heme oxygenase (HO1) has been associated with the loss of ICC and delayed GE. In a randomized controlled trial, hemin infusion with albumin was compared with albumin alone and its effect on HO1 levels. Patients received infusions on days 1,3 , and 8 and subsequent weekly infusions for 7 weeks. Beyond 1 week, hemin did not increase $\mathrm{HO} 1$ levels or improve symptoms or GE. ${ }^{87}$

\section{Drug-drug interactions}

A common clinical problem encountered in the management of patients with DMGP is drug-drug interactions. Typically, patients require a combination of antiemetics, prokinetic agents, and pain modulators. Prokinetic agents, such as domperidone and metoclopramide, have been associated with QT prolongation, ${ }^{88}$ and a combination of these regimens with antiemetics, such as promethazine and ondansetron, ${ }^{89}$ or antidepressants could have a synergistic effect. ${ }^{90,91}$ Due to the high prevalence of anxiety and depression in patients with GP, ${ }^{92}$ concomitant use of selective serotonin reuptake inhibitors and metoclopramide could also lead to a greater risk of side effects (Figure 3). ${ }^{93}$

The cardiotoxic effects of metoclopramide and domperidone were investigated in neonatal rat cardiomyocytes. Cardiotoxicity was deemed to be due to potent local anesthetic-like inhibition of cardiac $\mathrm{Na}$ channels ${ }^{94}$ and inhibition of hERG channel activity, which inhibits the rapid component of the cardiac delayed rectifier $\mathrm{K}^{(+)}$current. $^{88,95}$ Recently, a meta-analysis of observational studies reported a $70 \%$ increase in the risk of cardiac arrhythmia and sudden cardiac death with domperidone use ${ }^{88}$ However, these data should be regarded with caution given the poor methodological quality of each composite study. ${ }^{96}$ In our personal 20 years' experience with domperidone, it has demonstrated good clinical efficacy in doses of up to $120 \mathrm{mg} /$ day. Out of 64 patients treated with domperidone (DMGP 45\%, IDGP $36 \%$, and other $19 \%$ ), 10 patients had prolonged QTc ranging from 453 to 509; however, no clinical cardiovascular adverse events were reported. ${ }^{54}$ Baseline and routine follow-up electrocardiography testing should be performed in patients on domperidone, and more specifically, when these patients also require antiemetics, prokinetics, and antidepressants to monitor for QTc prolongation.

\section{Glycemic control and comorbidities in DMGP}

Acute and chronic hyperglycemia can delay $\mathrm{GE}^{97}$; however, there is limited data showing that long-term glucose control can improve GE. ${ }^{98}$ In the Epidemiology of Diabetes Intensive Complications study, elevated baseline $\mathrm{HbA} 1 \mathrm{c}$ and years of diabetes were associated with delayed GE in patients with T1DM. ${ }^{9}$ In healthy people, hyperglycemia (blood glucose $\geq 200 \mathrm{mg} / \mathrm{dL}$ ) reduces antral motility, ${ }^{99}$ and severe hyperglycemia (blood glucose 290-340 mg/dL) can reduce antral motility and GE in patients with T1DM. ${ }^{100}$ Furthermore, hyperglycemia (mean blood glucose $285 \mathrm{mg} /$ dL) may reduce the length of the MMC cycle. ${ }^{101}$ Thus, it is plausible that reduction in antral motility and MMC cycles may result in delayed GE.

Delayed GE may also be associated with hypoglycemia, and this condition has been termed "gastric" hypoglycemia. ${ }^{102}$ A study involving 31 patients with diabetes (16 T1DM and 15 T2DM) with unexplained postprandial hypoglycemia and 18 insulin-dependent patients with diabetes without postprandial hypoglycemia underwent $\mathrm{GE}{ }^{13} \mathrm{C}$ breath tests (BreathID ${ }^{\circledR}$ system). GE was slower in hypoglycemic patients with diabetes than in nonhypoglycemic patients with diabetes with $\mathrm{t}_{1 / 2} 139.9 \pm 74.1$ vs. $77.8 \pm 23.3(p<0.001) .{ }^{103}$

Blood glucose excursions due to poor tolerability of oral hypoglycemic agents or fear of insulin use during episodes of poor oral intake may lead to subsequent microvascular/ macrovascular complications and comorbidities. People with diabetes with GP symptoms and delayed GE have been associated with an increased risk of the development of cardiovascular disease $(p<0.05)$, hypertension $(p=0.005)$, and retinopathy $(p<0.001)$ but not with overall mortality when 


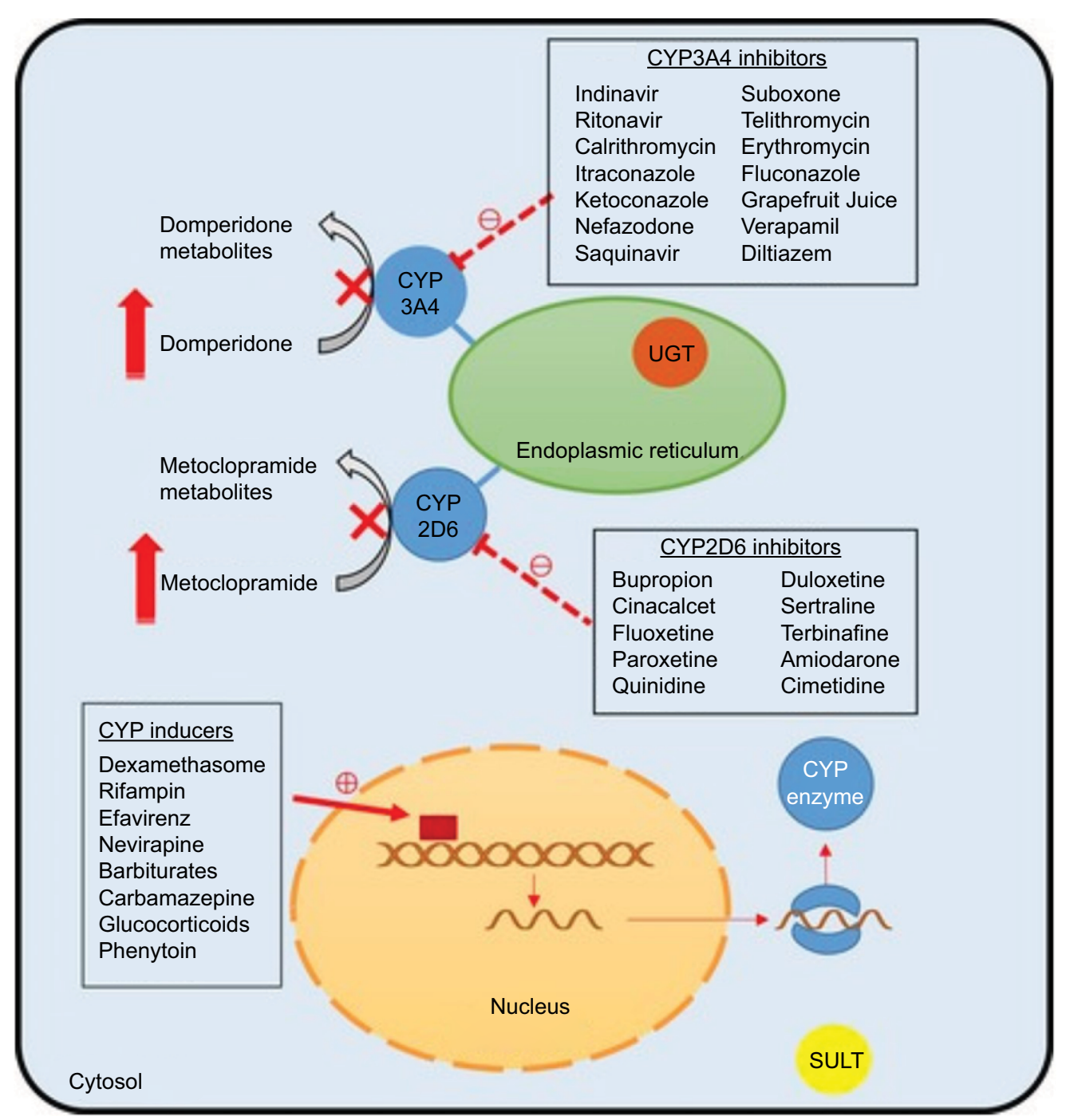

Figure 3 Potential drug-drug interactions in gastroparesis.

Note: Copyright @2015. John Wiley and Sons. Reproduced from Youssef AS, Parkman HP, Nagar S. Drug-drug interactions in pharmacologic management of gastroparesis. Neurogastroenterol Motil. 2015;27(II):1528-1541. ${ }^{93}$

Abbreviations: CYP, Cytochrome P450; UGT, glucuronosyltransferase; SULT, sulfotransferases.

compared with people with diabetes without GP symptoms and normal GE. ${ }^{104}$ Similarly, in a 25 -year follow-up study of 86 patients with DMGP, delayed GE of solid or liquid meals was not associated with increased mortality. ${ }^{105}$

\section{Nutrition and DMGP}

Dietary modifications are often needed to control gastroparetic symptoms. More frequently, small portions of a diabetic diet have been effective in reducing symptoms in DMGP. Fifty-six patients with insulin-dependent diabetes and GP were randomized to a small particle diet consisting of foods that could be easily mashed or ground and a control diet that consisted of large particle foods with a low glycemic index (i.e., whole meat, seafood, cheese slices, almonds, and nuts). Symptoms of nausea/vomiting ( $p=0.01)$, postprandial fullness ( $p=0.02$ ), bloating ( $p=0.006$ ), and heartburn/regurgitation $(p=0.02)$ were improved in the intervention arm, but no improvement was seen in abdominal pain. ${ }^{106}$ Similarly, avoidance of high-fat solid meals, implementation of a lowfat/low-fiber diet, and increased liquid content meals led to symptomatic improvement. ${ }^{107,108}$ Carbonated beverages should be avoided as they can aggravate proximal gastric distension and can theoretically worsen abdominal bloating and the sensation of fullness in DMGP. ${ }^{109}$

Patients with DMGP may have diets deficient in calories, vitamins, and minerals. ${ }^{110}$ Poor oral tolerance of a liquid meal may be a clinical sign for the need for an alternative means of nutrition. A trial of nasojejunal tube feedings may be used to assess tolerance of feedings ${ }^{111}$ and as a bridge to placement of a surgical jejunal tube. Surgical placement of 
a jejunostomy tube beyond the affected stomach has been shown to improve self-reported overall health status among patients with DMGP; however, up to $54 \%$ of patients may have some complications requiring further surgery or hospitalization. ${ }^{12}$ An alternative to surgical placement of a jejunostomy tube is a direct percutaneous endoscopic jejunostomy (DPEJ), which has been associated with modest technical success (68\%) and minimal adverse events, including bowel perforation $(2.4 \%)$, jejunal volvuli (1\%), and major bleeding (1\%). ${ }^{113}$ Per-endoscopic 20F gastrostomy tubes with extension (PEGJ) are technically easier to place than a 20F DPEJ; however, their placement is associated with a high degree of retrograde tube migration, ${ }^{114}$ which may often be seen in patients with DMGP after prolonged episodes of nausea/ vomiting and retching. Placement of endoscopic clips during the placement of a PEGJ ${ }^{115}$ and a new technique called the PEG-Pedi-PEG technique, ${ }^{116}$ which involves placement of a pediatric PEG tube bumper in the small bowel, may limit retrograde tube migration; however, reports of its clinical success in patients with DMGP are limited.

\section{QoL and biopsychosocial factors in DMGP}

Patients with DMGP have an impaired QoL due to symptoms of GP, and many will have concomitant mood disorders with nearly $50 \%$ of patients reporting anxiety and $38 \%$ of them reporting depression. ${ }^{117}$ Patients with mood disorders are more likely to report worse GP symptoms, ${ }^{92,118}$ and clinical symptoms, such as abdominal pain and nausea/vomiting, have been linked with an overall poorer QoL. ${ }^{119,120}$ Abdominal pain is the predominant symptom in one-fifth of patients with $\mathrm{GP}$, whereas nausea/vomiting is the predominant symptom in $44 \%$ of gastroparetics. ${ }^{120}$ Abdominal pain is often epigastric (43\%), postprandial (72\%), nocturnal (74\%), and frequently associated with interference with sleep (66\%). ${ }^{119,121}$ It is important to differentiate the entity of abdominal wall pain related to contractions of the rectus abdominis muscle during episodes of vomiting as opposed to visceral abdominal pain. Abdominal wall pain responds to anesthetic patches, heat pad applications, and breathing/relaxation techniques. ${ }^{122}$ Regardless of GP subtype, abdominal pain appears to be present in both DMGP (89\%) and IDGP (90\%), ${ }^{119}$ but moderate-severe upper abdominal pain is more prevalent in IDGP than in DMGP and correlates with other symptoms, such as nausea/vomiting, bloating, lower abdominal pain, bowel disturbances, and opiate use $(p<0.05) .{ }^{120}$ Prokinetics, such as relamorelin ${ }^{76}$ and prucalopride, ${ }^{83}$ have not been shown to improve symptoms of abdominal pain except for a metoclopramide nasal spray. ${ }^{45}$ The effects of domperidone on abdominal pain have shown conflicting results with one prospective study showing no improvement ${ }^{48}$ and another study reporting positive clinical outcomes. ${ }^{56}$ Data on symptomatic improvement with Velusetrag are still pending. ${ }^{84}$

It is conceivable that due to a lack of symptom control with traditional medications, patients with DMGP may resort to the use of narcotics for the alleviation of abdominal pain. In a recent study of 223 patients (27.8\% DMGP, 54.7\% IDGP, and $17.5 \%$ other) with delayed GE who were referred to a tertiary medical center, opioids were used in nearly one-third of participants, whereas $19.3 \%$ of these patients were on chronic opioids ( $>1$ month). Symptoms of upper abdominal pain, nausea, vomiting, retching, early satiety, and postprandial fullness were worse in patients on chronic opioids than in patients who were not on opioids $(p<0.05) .{ }^{123}$ Patients on chronic opioids also had greater interference with sleep due to abdominal pain, lower employment rates, fewer working hours among those employed, and a greater number of hospitalizations. ${ }^{123}$ Worsening symptoms of abdominal pain with opioid use may be multifactorial and due to narcotic bowel syndrome, opioid-induced constipation, worsening psychopathology, and addiction. ${ }^{124}$ In addition, opioids can further delay GE in patients with GP and lead to worsening symptoms. ${ }^{119,121,125}$

\section{Endoscopic/surgical interventions}

In DMGP, intrapyloric injection of botulinum toxin to the pylorus has resulted in unconvincing results in terms of clinical efficacy. ${ }^{126}$ However, with the advent of endoscopic ultrasonography, it is postulated that injection of botulinum toxin with direct ultrasonographic visualization to the muscularis propria of the pyloric sphincter will lead to better clinical outcomes. ${ }^{127,128}$ Endoscopic transpyloric stent placement has also been proposed as a salvage therapy and as a bridge to more permanent therapies, such as gastric electric stimulation (GES). In a prospective cohort of 30 patients with refractory GP, 48 transpyloric stents were placed, resulting in $98 \%$ technical and $75 \%$ clinical success. Stent migration was least common (48\%) when the stents were sutured to the gastric wall. ${ }^{129}$

Patients with refractory GP may be offered GES if medical treatment fails. The Enterra GES has been shown to be effective in clinical practice for patients with DMGP. Clinical parameters associated with favorable clinical responses include DMGP rather than IDGP as an indication, nausea/vomiting as a primary symptom as opposed to abdominal pain, and the absence of narcotic use prior to 
GES implantation. ${ }^{130}$ Complications of GES have included infection (3.9\%), device/lead migration (2.7\%), and pain at the implantation site $(0.7 \%) .{ }^{131}$ In a prospective cohort of 151 patients (72 DMGP, 73 IDGP, and 6 others), GES improved symptoms of nausea, vomiting, loss of appetite, and early satiety. ${ }^{132}$ The longest follow-up study showed that GES improved symptoms by $\sim 50 \%$; however, $75 \%$ of patients continued to have delayed GE during a follow-up period of up to 10 years. ${ }^{133}$ The addition of pyloroplasty was conceived as an adjunct to GES in order to normalize or improve GE and further reduce clinical symptoms in drugrefractory GP. A prospective cohort of 49 patients with GP (17 DMGP, 9 IDGP, and 23 postsurgical GP) showed that GE was $64 \%$ faster by 4 hours $(p<0.001)$ in patients who underwent GES+pyloroplasty compared with 7\% improvement in patients who underwent GES alone and symptoms were reduced by $>70 \% .{ }^{134}$ Simultaneous GES implantation and Heineke-Mikulicz pyloroplasty have not shown an increase in morbidity. ${ }^{135}$

Laparoscopic pyloroplasty as a first-line treatment in refractory GP has shown improvement in GE and a reduction of clinical symptoms. In a prospective cohort of 177 patients, 105 of whom also had a fundoplication for concurrent reflux, GE improved or normalized in $90 \%$ of patients with clinical improvement in symptoms of nausea, vomiting, bloating, and abdominal pain. ${ }^{136}$ Debate continues as to whether pyloroplasty alone will suffice, or a combination of GES implantation and pyloroplasty will lead to better clinical outcomes. A double-blind study is under current clinical investigation to address this question. Due to advancements of endoscopic techniques, gastric per-oral endoscopic pyloromyotomy (G-POEM) is a new nonsurgical treatment option for refractory GP and may be an alternative to laparoscopic pyloroplasty (Figure 4). In a prospective cohort of 47 patients who underwent G-POEM (27 IDGP, 12 DMGP, and 8 postsurgical GP), preprocedure meal retention at 4 hours was $37 \%$ compared with $20 \%(p<0.03)$ after G-POEM. ${ }^{137}$ In a separate cohort of 29 patients (15 IDGP, 7 DMGP, 5 postsurgical GP, and 2 scleroderma), clinical improvement (69\%) and GE normalization (70\%) were still present at a 6-month followup. ${ }^{138} \mathrm{~A}$ multicenter prospective study of G-POEM evaluated 30 patients with refractory GP (11 DMGP, 12 post-surgical GP and 7 IDGP), all of whom had a technically successful intervention with an average procedure time of 72 minutes. Two adverse events were reported (one capnoperitoneum and one prepyloric ulcer), and four patients did not respond to G-POEM. Most patients (86\%) had good clinical response, and GE improved or normalized in $35 \%$ and $47 \%$ of patients, respectively. ${ }^{139}$ The implementation of EndoFLIP may aid in patient selection for G-POEM as it can evaluate the pyloric sphincter compliance or resistance in symptomatic patients with nausea, vomiting, and delayed GE. ${ }^{140}$

\section{Synthesis of medical and surgical treatment approaches}

We provide a "progress report" of where we are in 2018, and this is best appreciated in the treatment algorithm (Figure 5). Since the approval of metoclopramide in 1980, $>35$ years have passed with no major therapeutic advances in prokinetics. Symptom improvement has been achieved through aggressive antiemetic therapy and, in some cases, acupuncture. We are now starting to witness a surge in drug development. In addition, recognition of pyloric dysfunction as an integral part of the pathophysiology of GP has set the stage for simultaneous GES implantation with pyloroplasty. Advances in endoscopic techniques have also allowed for an alternative to surgical pyloroplasty via endoscopic pyloromyotomy. The next decade will see the greatest therapeutic progress that we have witnessed in GP with the possibility of prevention and cure.

\section{Expert analysis and concluding commentary}

- Medical therapy should initially be pursued in all patients with DMGP. New pharmacological agents are rapidly evolving and are currently approaching the FDA approval stage. This will provide a "menu" of effective prokinetics.

- Antiemetic therapy is the foundation for gaining initial symptom control, and the agents available have different receptor targets in the chemoreceptor trigger zone. Strategic utilization of these agents alone and in combination is my recommendation.

- We have increased our knowledge of the pathophysiology of GP where we have extended beyond the observations of antral ICC depletion to understanding the unappreciated crucial role of pyloric damage in the pathophysiology of DMGP.

- Armed with this new understanding of the pathophysiology and specifically targeting the pylorus, we now have the surgical and endoscopic tools in hand as well as the clinical outcome data to confidently state that we have and can continue to successfully overcome GP.

- Certainly, I continue to recommend that medical therapy should be actively initiated but with knowledge that when responses are suboptimal, there should be no hesitation in turning to what I term the "the final solution" for GP with gastric neurostimulation "combined with a pyloroplasty". 
A

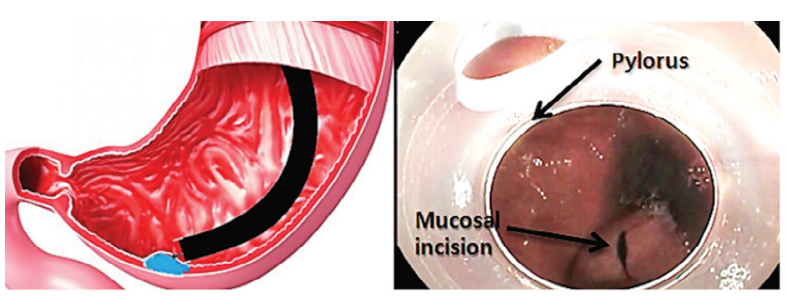

B

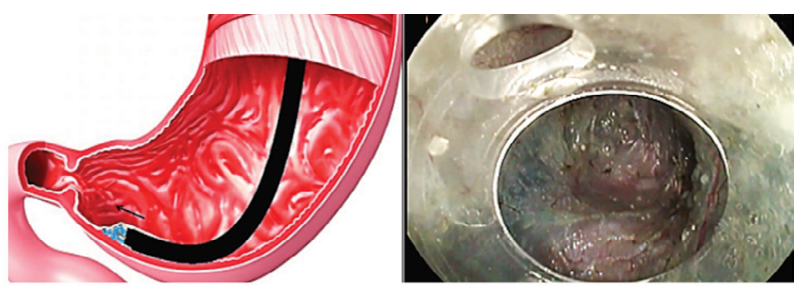

C

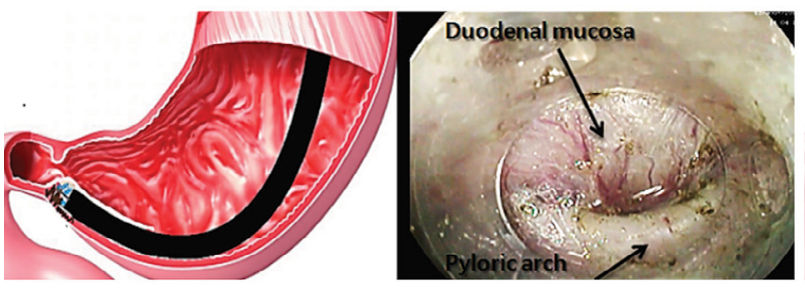

D

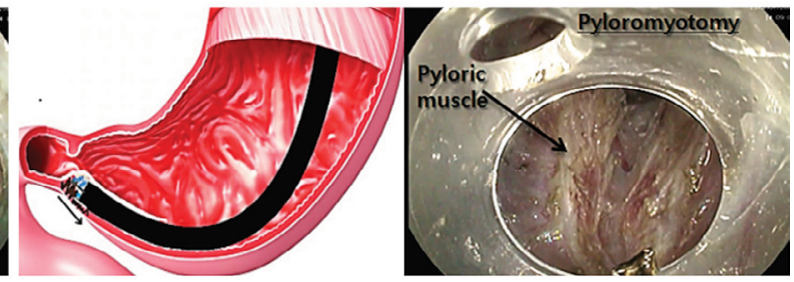

E

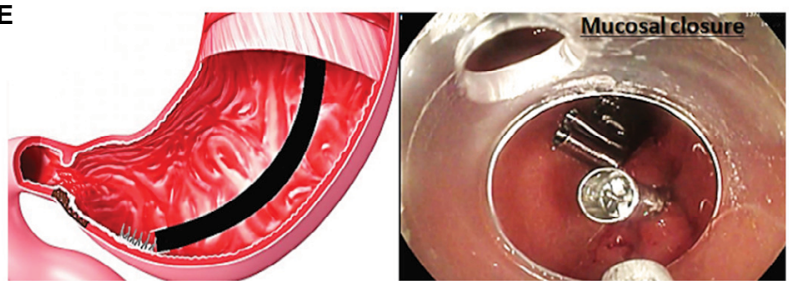

Figure 4 Gastric per-oral endoscopic pyloromyotomy for gastroparesis.

Notes: (A) Injection and submucosal incision performed in the posterolateral part of the antrum, 4 to $5 \mathrm{~cm}$ upstream from the pylorus. (B) Tunnel creation by submucosal dissection (Swift coagulation current, $35 \mathrm{~W}$ ) using a Triangle Knife (Olympus, Tokyo, Japan). (C) Endoscopic submucosal aspect of the pyloric muscle: "pyloric arch." (D) Myotomy of the pyloric and the antral muscular layers. (E) Mucosal access closure using through-the-scope clips. Reprinted from Gastrointestinal Endoscopy. 85(I), Gonzalez et al, Gastric per-oral endoscopic myotomy with antropyloromyotomy in the treatment of refractory gastroparesis: clinical experience with follow-up and scintigraphic evaluation (with video), 132-139, Copyright (2017), with permission from Elsevier.

Abbreviation: G-POEM, gastric per-oral endoscopic pyloromyotomy.

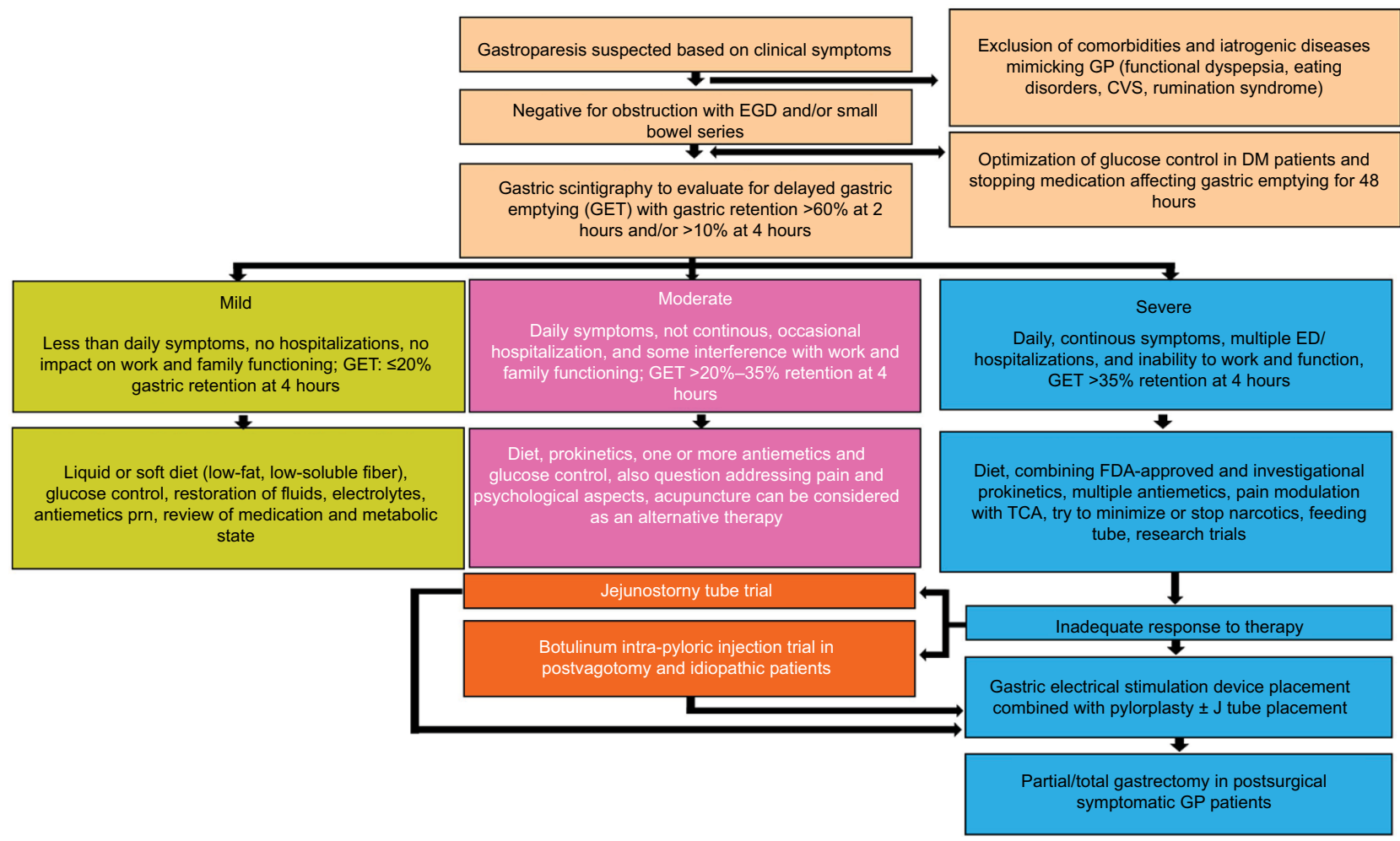

Figure 5 Treatment algorithm in diabetic gastroparesis.

Abbreviations: CVS, cyclic vomiting syndrome; DM, diabetes mellitus; ED, emergency department; EGD, esophagogastroduodenoscopy; FDA, U.S. Food and Drug Administration; GET, gastric emptying time; GP, gastroparesis; prn, as needed; TCA, tricyclic antidepressants. 
- Now, the focus is on prevention of GP by drilling down to the molecular level in the smooth muscle. New knowledge from M1 and M2 macrophages as well as inflammatory pathways has led to further understanding of how to prevent ICC depletion and damage to the enteric nervous system.

\section{Acknowledgments}

We would like to recognize how far this field has come and what has been accomplished, thanks to the National Institutes of Health and their decision to fund seven centers of academic excellence that constitute the Clinical Gastroparesis Consortium. Over the past 12 years, the consortium has made seminal contributions to advancing the field. We look forward to their continued leadership and discoveries in GP in the coming years.

\section{Disclosure}

The authors report no conflicts of interest in this work.

\section{References}

1. Lacy BE, Crowell MD, Mathis C, Bauer D, Heinberg LJ. Gastroparesis: quality of life and health care utilization. J Clin Gastroenterol. 2018;52(1):20-24.

2. Choung RS, Locke GR 3rd, Schleck CD, Zinsmeister AR, Melton LJ 3rd, Talley NJ. Risk of gastroparesis in subjects with type 1 and 2 diabetes in the general population. Am J Gastroenterol. 2012;107(1):82-88.

3. Parkman HP, Hallinan EK, Hasler WL, et al. Nausea and vomiting in gastroparesis: similarities and differences in idiopathic and diabetic gastroparesis. Neurogastroenterol Motil. 2016;28(12):1902-1914.

4. Parkman HP, Yates K, Hasler WL, et al. Similarities and differences between diabetic and idiopathic gastroparesis. Clin Gastroenterol Hepatol. 2011;9(12):1056-1064; quiz e1133-e1054.

5. Rao SS, Camilleri M, Hasler WL, et al. Evaluation of gastrointestinal transit in clinical practice: position paper of the American and European Neurogastroenterology and Motility Societies. Neurogastroenterol Motil. 2011;23(1):8-23.

6. Parkman HP, Hallinan EK, Hasler WL, et al. Early satiety and postprandial fullness in gastroparesis correlate with gastroparesis severity, gastric emptying, and water load testing. Neurogastroenterol Motil. 2017;29(4).

7. Koch KL, Hasler WL, Yates KP, et al. Baseline features and differences in 48 week clinical outcomes in patients with gastroparesis and type 1 vs. type 2 diabetes. Neurogastroenterol Motil. 2016;28(7):1001-1015.

8. Homko C, Siraj ES, Parkman HP. The impact of gastroparesis on diabetes control: patient perceptions. J Diabetes Complications. 2016;30(5):826-829.

9. Bharucha AE, Batey-Schaefer B, Cleary PA, et al. Delayed gastric emptying is associated with early and long-term hyperglycemia in type 1 diabetes mellitus. Gastroenterology. 2015;149(2):330-339.

10. Shen HL, Yang SP, Wang KJ, et al. Evaluation of gastric blood supply in diabetic patients with gastroparesis by contrast-enhanced ultrasound. Br J Radiol. 2016;89(1068):20160366.

11. Grover M, Farrugia G, Lurken MS, et al. Cellular changes in diabetic and idiopathic gastroparesis. Gastroenterology. 2011;140(5):15751585 e 1578 .

12. Iwasaki H, Kajimura M, Osawa S, et al. A deficiency of gastric interstitial cells of Cajal accompanied by decreased expression of neuronal nitric oxide synthase and substance $P$ in patients with type 2 diabetes mellitus. J Gastroenterol. 2006;41(11):1076-1087.
13. Deli G, Bosnyak E, Pusch G, Komoly S, Feher G. Diabetic neuropathies: diagnosis and management. Neuroendocrinology. 2013;98(4): 267-280.

14. Grover M, Bernard CE, Pasricha PJ, et al. Clinical-histological associations in gastroparesis: results from the Gastroparesis Clinical Research Consortium. Neurogastroenterol Motil. 2012;24(6):531-539.e249.

15. Kashyap P, Farrugia G. Oxidative stress: key player in gastrointestinal complications of diabetes. Neurogastroenterol Motil. 2011;23(2): 111-114.

16. Neshatian L, Gibbons SJ, Farrugia G. Macrophages in diabetic gastroparesis-the missing link? Neurogastroenterol Motil. 2015;27(1):7-18.

17. Bernard CE, Gibbons SJ, Mann IS, et al. Association of low numbers of CD206-positive cells with loss of ICC in the gastric body of patients with diabetic gastroparesis. Neurogastroenterol Motil. 2014;26(9):1275-1284.

18. Grover M, Bernard CE, Pasricha PJ, et al. Diabetic and idiopathic gastroparesis is associated with loss of CD206-positive macrophages in the gastric antrum. Neurogastroenterol Motil. 2017;29(6).

19. Heckert J, Thomas RM, Parkman HP. Gastric neuromuscular histology in patients with refractory gastroparesis: relationships to etiology, gastric emptying, and response to gastric electric stimulation. Neurogastroenterol Motil. 2017;29(8).

20. Mohammad MK, Pepper DJ, Kedar A, et al. Measures of autonomic dysfunction in diabetic and idiopathic gastroparesis. Gastroenterol. Res. 2016;9(4-5):65-69.

21. Horvath VJ, Vittal H, Lorincz A, et al. Reduced stem cell factor links smooth myopathy and loss of interstitial cells of cajal in murine diabetic gastroparesis. Gastroenterology. 2006;130(3):759-770.

22. Mearin F, Camilleri M, Malagelada JR. Pyloric dysfunction in diabetics with recurrent nausea and vomiting. Gastroenterology. 1986;90(6):1919-1925.

23. Moraveji S, Bashashati M, Elhanafi S, et al. Depleted interstitial cells of Cajal and fibrosis in the pylorus: novel features of gastroparesis. Neurogastroenterol Motil. 2016;28(7):1048-1054.

24. Malik Z, Sankineni A, Parkman HP. Assessing pyloric sphincter pathophysiology using EndoFLIP in patients with gastroparesis. Neurogastroenterol Motil. 2015;27(4):524-531.

25. Hasler WL, May KP, Wilson LA, et al. Relating gastric scintigraphy and symptoms to motility capsule transit and pressure findings in suspected gastroparesis. Neurogastroenterol Motil. 2017;30(2).

26. Midani D, Parkman HP. Granisetron transdermal system for treatment of symptoms of gastroparesis: a prescription registry study. $J$ Neurogastroenterol Motil. 2016;22(4):650-655.

27. Fountoulakis N, Dunn J, Thomas S, Karalliedde J. Successful management of refractory diabetic gastroparesis with long-term Aprepitant treatment. Diabet Med. 2017;34(10):1483-1486.

28. Pasricha PJ, Yates K, Sarosiek I, et al. Aprepitant for symptoms of gastroparesis and related disorders: the apron randomized clinical trial. Am J Gastroenterol. 2016;111:S480-S481.

29. Pasricha PJ, Yates KP, Sarosiek I, et al. Aprepitant has mixed effects on nausea and reduces other symptoms in patients with gastroparesis and related disorders. Gastroenterology. 2018;154(1):65-76.e11.

30. ClinicalTrials.gov. Study to Assess the Efficacy of VLY-686 in Relieving Symptoms of Gastroparesis. 2017. Available from: https:// clinicaltrials.gov/ct2/show/study/NCT02970968. Accessed September 16th, 2017.

31. Huilgol V, Evans J, Hellman RS, Soergel KH. Acute effect of clonidine on gastric emptying in patients with diabetic gastropathy and controls. Aliment Pharmacol Ther. 2002;16(5):945-950.

32. Rosa-e-Silva L, Troncon LE, Oliveira RB, Iazigi N, Gallo L Jr, Foss MC. Treatment of diabetic gastroparesis with oral clonidine. Aliment Pharmacol Ther. 1995;9(2):179-183.

33. Thumshirn M, Camilleri M, Choi MG, Zinsmeister AR. Modulation of gastric sensory and motor functions by nitrergic and alpha2-adrenergic agents in humans. Gastroenterology. 1999;116(3):573-585.

34. Danielli Miller N, Schiff E, Ben-Arye E, et al. Benefits of acupuncture for diabetic gastroparesis: a comparative preliminary study. Acupunct Med. 2014;32(2):139-145. 
35. Yang M, Li X, Liu S, et al. Meta-analysis of acupuncture for relieving non-organic dyspeptic symptoms suggestive of diabetic gastroparesis. BMC Complement Altern Med. 2013;13:311.

36. Sarosiek I, Song G, Sun Y, et al. Central and peripheral effects of transcutaneous acupuncture treatment for nausea in patients with diabetic gastroparesis. J Neurogastroenterol Motil. 2017;23(2):245-253.

37. McCallum RW, Soykan I, Sridhar KR, Ricci DA, Lange RC, Plankey MW. Delta-9-tetrahydrocannabinol delays the gastric emptying of solid food in humans: a double-blind, randomized study. Aliment Pharmacol Ther. 1999;13(1):77-80.

38. Stanghellini V, Talley NJ, Chan F, et al. Rome IV-gastroduodenal disorders. Gastroenterology. Epub2016 Feb 15.

39. US Food and Drug Administration. FDA Approved Drug Products. 1980.Available from: https:/www.accessdata.fda.gov/scripts/cder/daf/ index.cfm? event $=$ overview.process $\&$ varApplNo=017854. Accessed September 16, 2017.

40. Metoclopramide (Reglan). Med Lett Drugs Ther. 1982;24(614):67-69.

41. US Food and Drug Administration. FDA Requires Boxed Warning and Risk Mitigation Strategy for Metoclopramide-Containing Drugs. 2009. Available from: https://www.accessdata.fda.gov/drugsatfda_docs/ label/2009/017854s052lbl.pdf. Accessed September 16, 2017.

42. Ehrenpreis ED, Deepak P, Sifuentes H, Devi R, Du H, Leikin JB. The metoclopramide black box warning for tardive dyskinesia: effect on clinical practice, adverse event reporting, and prescription drug lawsuits. Am J Gastroenterol. 2013;108(6):866-872.

43. Parkman HP, Mishra A, Jacobs M, et al. Clinical response and side effects of metoclopramide: associations with clinical, demographic, and pharmacogenetic parameters. J Clin Gastroenterol. 2012;46(6):494-503.

44. Parkman HP, Carlson MR, Gonyer D. Metoclopramide nasal spray is effective in symptoms of gastroparesis in diabetics compared to conventional oral tablet. Neurogastroenterol Motil. 2014;26(4):521-528.

45. McCallum RW, Fass R, Bhandari BR, Carlson MR, Alves W. Symptom severity influences drug efficacy in women with diabetic gastroparesis results of a phase 3 study with metoclopramide nasal spray. Gastroenterology. 2017;152(5):S1313.

46. Braun AP. Domperidone in the treatment of symptoms of delayed gastric emptying in diabetic patients. Adv Ther. 1989;6(2):51-62.

47. Franzese A, Borrelli O, Corrado G, et al. Domperidone is more effective than cisapride in children with diabetic gastroparesis. Aliment Pharmacol Ther. 2002;16(5):951-957.

48. Heckert J, Parkman HP. Therapeutic response to domperidone in gastroparesis: a prospective study using the GCSI-daily diary. Neurogastroenterol Motil. 2018;30(1).

49. Heer M, Muller-Duysing W, Benes I, et al. Diabetic gastroparesis: treatment with domperidone - a double-blind, placebo-controlled trial. Digestion. 1983;27(4):214-217.

50. Horowitz M, Harding PE, Chatterton BE, Collins PJ, Shearman DJ. Acute and chronic effects of domperidone on gastric emptying in diabetic autonomic neuropathy. Dig Dis Sci. 1985;30(1):1-9.

51. Koch KL, Stern RM, Stewart WR, Vasey MW. Gastric emptying and gastric myoelectrical activity in patients with diabetic gastroparesis: effect of long-term domperidone treatment. Am J Gastroenterol. 1989;84(9): 1069-1075.

52. Kozarek R. Domperidone for symptomatic management of diabetic gastroparesis in metoclopramide treatment failures. Advances in Therapy. 1990;7(2):61-68.

53. Nagler J, Miskovitz P. Clinical evaluation of domperidone in the treatment of chronic postprandial idiopathic upper gastrointestinal distress. Am J Gastroenterol. 1981;76(6):495-499.

54. Ortiz A, Cooper CJ, Alvarez A, Gomez Y, Sarosiek I, McCallum RW. Cardiovascular safety profile and clinical experience with highdose domperidone therapy for nausea and vomiting. Am J Med Sci. 2015;349(5):421-424.

55. Patterson D, Abell T, Rothstein R, Koch K, Barnett J. A double-blind multicenter comparison of domperidone and metoclopramide in the treatment of diabetic patients with symptoms of gastroparesis. Am J Gastroenterol. 1999;94(5):1230-1234.
56. Schey R, Saadi M, Midani D, Roberts AC, Parupalli R, Parkman HP. Domperidone to treat symptoms of gastroparesis: benefits and side effects from a large single-center cohort. Dig Dis Sci. 2016;61(12):3545-3551.

57. Silvers D, Kipnes M, Broadstone V, et al. Domperidone in the management of symptoms of diabetic gastroparesis: efficacy, tolerability, and quality-of-life outcomes in a multicenter controlled trial. DOM-USA-5 Study Group. Clin Ther. 1998;20(3):438-453.

58. Soykan I, Sarosiek I, McCallum RW. The effect of chronic oral domperidone therapy on gastrointestinal symptoms, gastric emptying, and quality of life in patients with gastroparesis. Am J Gastroenterol. 1997;92(6):976-980.

59. Watts GF, Armitage M, Sinclair J, Hill RD. Treatment of diabetic gastroparesis with oral domperidone. Diabet Med. 1985;2(6): 491-492.

60. Sugumar A, Singh A, Pasricha PJ. A systematic review of the efficacy of domperidone for the treatment of diabetic gastroparesis. Clin Gastroenterol Hepatol. 2008;6(7):726-733.

61. De Colle C, van der Hart M, Chen J, Rassoulpour A, Pasricha PJ. 1079 NG101: a potent and selective dopamine $\mathrm{D}_{2}$ receptor antagonist as a potential alternative to metoclopramide and domperidone for the treatment of gastroparesis. Gastroenterology. 2016;150(4):S214

62. Farrugia G, Macielag MJ, Peeters TL, Sarr MG, Galdes A, Szurszewski JH. Motilin and OHM-11526 activate a calcium current in human and canine jejunal circular smooth muscle. Am J Physiol. 1997;273(2 Pt 1):G404-G412.

63. Maganti K, Onyemere K, Jones MP. Oral erythromycin and symptomatic relief of gastroparesis: a systematic review. Am J Gastroenterol. 2003;98(2):259-263.

64. Parkman HP, Pagano AP, Vozzelli MA, Ryan JP. Gastrokinetic effects of erythromycin: myogenic and neurogenic mechanisms of action in rabbit stomach. Am J Physiol. 1995;269(3 Pt 1):G418-G426.

65. Richards RD, Davenport K, McCallum RW. The treatment of idiopathic and diabetic gastroparesis with acute intravenous and chronic oral erythromycin. Am J Gastroenterol. 1993;88(2):203-207.

66. Talley NJ, Verlinden M, Geenen DJ, et al. Effects of a motilin receptor agonist (ABT-229) on upper gastrointestinal symptoms in type 1 diabetes mellitus: a randomised, double blind, placebo controlled trial. Gut. 2001;49(3):395-401.

67. Dhir R, Richter JE. Erythromycin in the short- and long-term control of dyspepsia symptoms in patients with gastroparesis. J Clin Gastroenterol. 2004;38(3):237-242.

68. Chini P, Toskes PP, Waseem S, Hou W, McDonald R, Moshiree B. Effect of azithromycin on small bowel motility in patients with gastrointestinal dysmotility. Scand J Gastroenterol. 2012;47(4):422-427.

69. Moshiree B, McDonald R, Hou W, Toskes PP. Comparison of the effect of azithromycin versus erythromycin on antroduodenal pressure profiles of patients with chronic functional gastrointestinal pain and gastroparesis. Dig Dis Sci. 2010;55(3):675-683.

70. Potter TG, Snider KR. Azithromycin for the treatment of gastroparesis. Ann Pharmacother. 2013;47(3):411-415

71. Janssen P, Harris MS, Jones M, et al. The relation between symptom improvement and gastric emptying in the treatment of diabetic and idiopathic gastroparesis. Am J Gastroenterol. 2013;108(9):1382-1391.

72. Collden G, Tschop MH, Muller TD. Therapeutic potential of targeting the ghrelin pathway. Int J Mol Sci. 2017;18(4):E798.

73. Shin A, Camilleri M, Busciglio I, et al. The ghrelin agonist RM-131 accelerates gastric emptying of solids and reduces symptoms in patients with type 1 diabetes mellitus. Clin Gastroenterol Hepatol. 2013;11(11):1453-1459.e54.

74. Shin A, Camilleri M, Busciglio I, et al. Randomized controlled phase Ib study of ghrelin agonist, RM-131, in type 2 diabetic women with delayed gastric emptying: pharmacokinetics and pharmacodynamics. Diabetes Care. 2013;36(1):41-48.

75. Camilleri M, McCallum RW, Tack J, Spence SC, Gottesdiener K, Fiedorek FT. Efficacy and safety of relamorelin in diabetics with symptoms of gastroparesis: a randomized, placebo-controlled study. Gastroenterology. 2017;153(5):1240-1250.e2 
76. Lembo A, Camilleri M, McCallum R, et al. Relamorelin reduces vomiting frequency and severity and accelerates gastric emptying in adults with diabetic gastroparesis. Gastroenterology. 2016;151(1):87-96.e6.

77. Bouras EP, Camilleri M, Burton DD, McKinzie S. Selective stimulation of colonic transit by the benzofuran 5HT4 agonist, prucalopride, in healthy humans. Gut. 1999;44(5):682-686.

78. De Schryver AM, Andriesse GI, Samsom M, Smout AJ, Gooszen HG, Akkermans LM. The effects of the specific 5HT(4) receptor agonist, prucalopride, on colonic motility in healthy volunteers. Aliment Pharmacol Ther. 2002;16(3):603-612.

79. Kessing BF, Smout AJ, Bennink RJ, Kraaijpoel N, Oors JM, Bredenoord AJ. Prucalopride decreases esophageal acid exposure and accelerates gastric emptying in healthy subjects. Neurogastroenterol Motil. 2014;26(8):1079-1086.

80. Braden B, Enghofer M, Schaub M, Usadel KH, Caspary WF, Lembcke B. Long-term cisapride treatment improves diabetic gastroparesis but not glycaemic control. Aliment Pharmacol Ther. 2002;16(7):1341-1346.

81. Degen L, Petrig C, Studer D, Schroller S, Beglinger C. Effect of tegaserod on gut transit in male and female subjects. Neurogastroenterol Motil. 2005;17(6):821-826.

82. Tack J, Camilleri M, Chang L, et al. Systematic review: cardiovascular safety profile of 5-HT(4) agonists developed for gastrointestinal disorders. Aliment Pharmacol Ther. 2012;35(7):745-767.

83. Carbone F, Rotondo A, Andrews C, et al. OP054-LB1A controlled cross-over trial shows benefit of prucalopride for symptom control and gastric emptying in gastroparesis. UEG Suppl Abstracts. 2015;3(6):561-571.

84. Ahn A, Barnes C, Shaywitz D, Grimaldi M, Canafax DM. Velusetrag improves gastric emptying time in subjects with diabetic or idiopathic gastroparesis. Gastroenterology. 2015;148(4):S507.

85. Smith JA, Beattie DT, Marquess D, Shaw JP, Vickery RG, Humphrey PP. The in vitro pharmacological profile of TD-5108, a selective 5-HT(4) receptor agonist with high intrinsic activity. Naunyn Schmiedebergs Arch Pharmacol. 2008;378(1):125-137.

86. Eisenman ST, Gibbons SJ, Verhulst PJ, Cipriani G, Saur D, Farrugia G. Tumor necrosis factor alpha derived from classically activated "M1"macrophages reduces interstitial cell of Cajal numbers. Neurogastroenterol Motil. 2017;29(4).

87. Bharucha AE, Daley SL, Low PA, et al. Effects of hemin on heme oxygenase-1, gastric emptying, and symptoms in diabetic gastroparesis. Neurogastroenterol Motil. 2016;28(11):1731-1740.

88. Leelakanok N, Holcombe A, Schweizer ML. Domperidone and risk of ventricular arrhythmia and cardiac death: a systematic review and meta-analysis. Clin Drug Investig. 2016;36(2):97-107.

89. Baguley WA, Hay WT, Mackie KP, Cheney FW, Cullen BF. Cardiac dysrhythmias associated with the intravenous administration of ondansetron and metoclopramide. Anesth Analg. 1997;84(6):1380-1381.

90. Digby G, Machaalany J, Malik P, et al. Multifactorial QT interval prolongation. Cardiol J. 2010;17(2):184-188.

91. Digby GC, Perez Riera AR, Barbosa Barros R, et al. Acquired long QT interval: a case series of multifactorial QT prolongation. Clin Cardiol. 2011;34(9):577-582.

92. Hasler WL, Parkman HP, Wilson LA, et al. Psychological dysfunction is associated with symptom severity but not disease etiology or degree of gastric retention in patients with gastroparesis. Am J Gastroenterol. 2010;105(11):2357-2367.

93. Youssef AS, Parkman HP, Nagar S. Drug-drug interactions in pharmacologic management of gastroparesis. Neurogastroenterol Motil. 2015;27(11):1528-1541.

94. Stoetzer C, Voelker M, Doll T, Heineke J, Wegner F, Leffler A. Cardiotoxic antiemetics metoclopramide and domperidone block cardiac voltage-gated $\mathrm{Na}^{+}$channels. Anesth Analg. 2017;124(1):52-60.

95. Rossi M, Giorgi G. Domperidone and long QT syndrome. Curr Drug Saf. 2010;5(3):257-262.

96. Bashashati M, Sarosiek I, Siddiqui T, McCallum RW. Adverse effects of domperidone: prolonged QuesT for knowledge? Dig Dis Sci. 2016;61(12):3384-3386.
97. Halland M, Bharucha AE. Relationship between control of glycemia and gastric emptying disturbances in diabetes mellitus. Clin Gastroenterol Hepatol. 2016;14(7):929-936.

98. Jones KL, Russo A, Berry MK, Stevens JE, Wishart JM, Horowitz M. A longitudinal study of gastric emptying and upper gastrointestinal symptoms in patients with diabetes mellitus. Am JMed. 2002;113(6):449-455.

99. Hasler WL, Soudah HC, Dulai G, Owyang C. Mediation of hyperglycemia-evoked gastric slow-wave dysrhythmias by endogenous prostaglandins. Gastroenterology. 1995;108(3):727-736.

100. Samsom M, Akkermans LM, Jebbink RJ, van Isselt H, vanBergeHenegouwen GP, Smout AJ. Gastrointestinal motor mechanisms in hyperglycaemia induced delayed gastric emptying in type I diabetes mellitus. Gut. 1997;40(5):641-646.

101. Oster-Jorgensen E, Qvist N, Pedersen SA, Rasmussen L, Hovendal $\mathrm{CP}$. The influence of induced hyperglycaemia on the characteristics of intestinal motility and bile kinetics in healthy men. Scand J Gastroenterol. 1992;27(4):285-288.

102. Horowitz M, Jones KL, Rayner CK, Read NW. 'Gastric' hypoglycaemia - an important concept in diabetes management. Neurogastroenterol Motil. 2006;18(6):405-407.

103. Lysy J, Israeli E, Strauss-Liviatan N, Goldin E. Relationships between hypoglycaemia and gastric emptying abnormalities in insulin-treated diabetic patients. Neurogastroenterol Motil. 2006;18(6):433-440.

104. Hyett B, Martinez FJ, Gill BM, et al. Delayed radionucleotide gastric emptying studies predict morbidity in diabetics with symptoms of gastroparesis. Gastroenterology. 2009;137(2):445-452.

105. Chang J, Rayner CK, Jones KL, Horowitz M. Prognosis of diabetic gastroparesis - a 25-year evaluation. Diabet Med. 2013;30(5):e185-e188.

106. Olausson EA, Storsrud S, Grundin H, Isaksson M, Attvall S, Simren M. A small particle size diet reduces upper gastrointestinal symptoms in patients with diabetic gastroparesis: a randomized controlled trial. Am J Gastroenterol. 2014;109(3):375-385.

107. Homko CJ, Duffy F, Friedenberg FK, Boden G, Parkman HP. Effect of dietary fat and food consistency on gastroparesis symptoms in patients with gastroparesis. Neurogastroenterol Motil. 2015;27(4):501-508.

108. Yu K, Ke MY, Li WH, Zhang SQ, Fang XC. The impact of soluble dietary fibre on gastric emptying, postprandial blood glucose and insulin in patients with type 2 diabetes. Asia Pac J Clin Nutr. 2014;23(2):210-218.

109. Pouderoux P, Friedman N, Shirazi P, Ringelstein JG, Keshavarzian A. Effect of carbonated water on gastric emptying and intragastric meal distribution. Dig Dis Sci. 1997;42(1):34-39.

110. Parkman HP, Yates KP, Hasler WL, et al. Dietary intake and nutritional deficiencies in patients with diabetic or idiopathic gastroparesis. Gastroenterology. 2011;141(2):486-498, 498.e1-e7.

111. Camilleri M, Parkman HP, Shafi MA, Abell TL, Gerson L, American College of Gastroenterology. Clinical guideline: management of gastroparesis. Am J Gastroenterol. 2013;108(1):18-37;quiz 38.

112. Fontana RJ, Barnett JL. Jejunostomy tube placement in refractory diabetic gastroparesis: a retrospective review. Am J Gastroenterol. 1996;91(10):2174-2178.

113. Maple JT, Petersen BT, Baron TH, Gostout CJ, Wong Kee Song LM, Buttar NS. Direct percutaneous endoscopic jejunostomy: outcomes in 307 consecutive attempts. Am J Gastroenterol. 2005;100(12):2681-2688.

114. Fan AC, Baron TH, Rumalla A, Harewood GC. Comparison of direct percutaneous endoscopic jejunostomy and PEG with jejunal extension. Gastrointest Endosc. 2002;56(6):890-894.

115. Udorah MO, Fleischman MW, Bala V, Cai Q. Endoscopic clips prevent displacement of intestinal feeding tubes: a long-term follow-up study. Dig Dis Sci. 2010;55(2):371-374.

116. Samarasena JB, Kwak NH, Chang KJ, Lee JG. The PEG-Pedi-PEG technique: a novel method for percutaneous endoscopic gastrojejunostomy tube placement (with video). Gastrointest Endosc. 2016;84(6):1030-1033.

117. Teigland T, Iversen MM, Sangnes DA, Dimcevski G, Softeland E. A longitudinal study on patients with diabetes and symptoms of gastroparesis - associations with impaired quality of life and increased depressive and anxiety symptoms. J Diabetes Complications. 2018;32(1):89-94. 
118. Pasricha PJ, Yates KP, Nguyen L, et al. Outcomes and factors associated with reduced symptoms in patients with gastroparesis. Gastroenterology. 2015;149(7):1762-1774.e4.

119. Cherian D, Sachdeva P, Fisher RS, Parkman HP. Abdominal pain is a frequent symptom of gastroparesis. Clin Gastroenterol Hepatol. 2010;8(8):676-681.

120. Hasler WL, Wilson LA, Parkman HP, et al. Factors related to abdominal pain in gastroparesis: contrast to patients with predominant nausea and vomiting. Neurogastroenterol Motil. 2013;25(5):427-438, e300-e301.

121. Hoogerwerf WA, Pasricha PJ, Kalloo AN, Schuster MM. Pain: the overlooked symptom in gastroparesis. Am J Gastroenterol. 1999;94(4):1029-1033.

122. Boelens OB, Scheltinga MR, Houterman S, Roumen RM. Randomized clinical trial of trigger point infiltration with lidocaine to diagnose anterior cutaneous nerve entrapment syndrome. Br J Surg. 2013;100(2):217-221.

123. Jehangir A, Parkman HP. Chronic opioids in gastroparesis: relationship with gastrointestinal symptoms, healthcare utilization and employment. World J Gastroenterol. 2017;23(40):7310-7320.

124. Szigethy E, Knisely M, Drossman D. Opioid misuse in gastroenterology and non-opioid management of abdominal pain. Nat Rev Gastroenterol Hepatol. 2018;15(3):168-180.

125. Jeong ID, Camilleri M, Shin A, et al. A randomised, placebo-controlled trial comparing the effects of tapentadol and oxycodone on gastrointestinal and colonic transit in healthy humans. Aliment Pharmacol Ther. 2012;35(9):1088-1096.

126. Ukleja A, Tandon K, Shah K, Alvarez A. Endoscopic botox injections in therapy of refractory gastroparesis. World J Gastrointest Endosc. 2015;7(8):790-798.

127. Yin G, Tan W, Hu D. Endoscopic ultrasonography-guided intrapyloric injection of botulinum toxin to treat diabetic gastroparesis. Dig Endosc. 2016;28(7):759.

128. Guo H, Fang C, Huang Y, et al. Treatment of diabetic gastroparesis with botulinum toxin injection guided by endoscopic ultrasound in a patient with type 1 diabetes: the first report. Acta Diabetol. 2017;54(5):509-511.

129. Khashab MA, Besharati S, Ngamruengphong S, et al. Refractory gastroparesis can be successfully managed with endoscopic transpyloric stent placement and fixation (with video). Gastrointest Endosc. 2015;82(6):1106-1109.

130. Maranki JL, Lytes V, Meilahn JE, et al. Predictive factors for clinical improvement with Enterra gastric electric stimulation treatment for refractory gastroparesis. Dig Dis Sci. 2008;53(8):2072-2078.
131. Chu H, Lin Z, Zhong L, McCallum RW, Hou X. Treatment of highfrequency gastric electrical stimulation for gastroparesis. J Gastroenterol Hepatol. 2012;27(6):1017-1026.

132. Heckert J, Sankineni A, Hughes WB, Harbison S, Parkman H. Gastric electric stimulation for refractory gastroparesis: a prospective analysis of 151 patients at a single center. Dig Dis Sci. 2016;61(1):168-175.

133. McCallum RW, Lin Z, Forster J, Roeser K, Hou Q, Sarosiek I. Gastric electrical stimulation improves outcomes of patients with gastroparesis for up to 10 years. Clin Gastroenterol Hepatol. 2011;9(4): 314-319.e1.

134. Sarosiek I, Forster J, Lin Z, Cherry S, Sarosiek J, McCallum R. The addition of pyloroplasty as a new surgical approach to enhance effectiveness of gastric electrical stimulation therapy in patients with gastroparesis. Neurogastroenterol Motil. 2013;25(2):e134-e180.

135. Davis BR, Sarosiek I, Bashashati M, Alvarado B, McCallum RW. The long-term efficacy and safety of pyloroplasty combined with gastric electrical stimulation therapy in gastroparesis. J Gastrointest Surg. 2017;21(2):222-227.

136. Shada AL, Dunst CM, Pescarus R, et al. Laparoscopic pyloroplasty is a safe and effective first-line surgical therapy for refractory gastroparesis. Surg Endosc. 2016;30(4):1326-1332.

137. Rodriguez JH, Haskins IN, Strong AT, et al. Per oral endoscopic pyloromyotomy for refractory gastroparesis: initial results from a single institution. Surg Endosc. 2017;31(12):5381-5388.

138. Gonzalez JM, Benezech A, Vitton V, Barthet M. G-POEM with antropyloromyotomy for the treatment of refractory gastroparesis: mid-term follow-up and factors predicting outcome. Aliment Pharmacol Ther. 2017;46(3):364-370.

139. Khashab MA, Ngamruengphong S, Carr-Locke D, et al. Gastric peroral endoscopic myotomy for refractory gastroparesis: results from the first multicenter study on endoscopic pyloromyotomy (with video) Gastrointest Endosc. 2017;85(1):123-128.

140. Snape WJ, Lin MS, Agarwal N, Shaw RE. Evaluation of the pylorus with concurrent intraluminal pressure and EndoFLIP in patients with nausea and vomiting. Neurogastroenterol Motil. 2016;28(5): $758-764$

141. Owyang C. Phenotypic switching in diabetic gastroparesis: mechanism directs therapy. Gastroenterology. 2011;141(4):1134-1137.

142. Gonzalez JM, Lestelle V, Benezech A et al. Gastric per-oral endoscopic myotomy with antropyloromyotomy in the treatment of refractory gastroparesis: clinical experience with follow-up and scintigraphic evaluation (with video). Gastrointest Endosc. 2017;85(1):132-139.
Clinical and Experimental Gastroenterology

\section{Publish your work in this journal}

Clinical and Experimental Gastroenterology is an international, peerreviewed, open access, online journal publishing original research, reports, editorials, reviews and commentaries on all aspects of gastroenterology in the clinic and laboratory. This journal is included on PubMed. The manuscript management system is completely online

\section{Dovepress}

and includes a very quick and fair peer-review system, which is all easy to use. Visit http://www.dovepress.com/testimonials.php to read real quotes from published authors. 